\title{
Scenario Development for the Waste Isolation Pilot Plant Compliance Certification Application
}

\author{
D.A. Galson ${ }^{1}$, P.N. Swift ${ }^{2}$, D.R. Anderson ${ }^{2}$, D.G. Bennett ${ }^{1}$, \\ M.B. Crawford ${ }^{1}$, T.W. Hicks ${ }^{1}$, R.D. Wilmot ${ }^{1}$, and George Basabilvazo ${ }^{3}$ \\ 'Galson Sciences Limited, 5 Grosvenor House, Melton Road, Oakham, Rutland LEI5 6AX, 9 \\ ${ }^{2}$ Sandia National Laboratories, P.O. Box 5800, Albuquerque, NM 87185, USA \\ ${ }^{3}$ United States Department of Energy, P.O. Box 3090, Carlsbad, NM 88221, USA

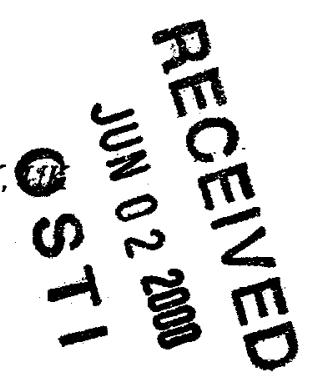

\section{ABSTRACT}

Demonstrating compliance with the applicable regulations for the Waste Isolation Pilot Plant (WIPP) requires an assessment of the long-term performance of the disposal system. Scenario development is one starting point of this assessment, and generates inquiry about the present state and future evolution of the disposal system. Scenario development consists of four tasks: (i) identifying and classifying features, events and processes (FEPs), (ii) screening FEPs according to well-defined criteria, (iii) forming scenarios (combinations of FEPs) in the context of regulatory performance criteria, and (iv) specifying of scenarios for consequence analysis. The development and screening of a comprehensive FEP list provides assurance that the identification of significant processes and events is complete, that potential interactions between FEPs are not overlooked, and that responses to possible questions are available and well documented. Two basic scenarios have been identified for the WIPP: undisturbed performance (UP) and disturbed performance (DP). The UP scenario is used to evaluate compliance with the Environmental Protection Agency's (EPA's) Individual Dose (40 CFR §191.15) and Groundwater Protection (40 CFR §191.24) standards and accounts for all natural and waste- and repository-induced FEPs that survive the screening process. The DP scenario is required for assessment calculations for the EPA's cumulative release standard (Containment Requirements, 40 CFR \$191.13) and accounts for disruptive future human events, which have an uncertain probability of occurrence, in addition to the UP FEPs. 


\section{DISCLAIMER}

This report was prepared as an account of work sponsored by an agency of the United States Government. Neither the United States Government nor any agency thereof, nor any of their employees, make any warranty, express or implied, or assumes any legal liability or responsibility for the accuracy, completeness, or usefulness of any information, apparatus, product, or process disclosed, or represents that its use would not infringe privately owned rights. Reference herein to any specific commercial product, process, or service by trade name, trademark, manufacturer, or otherwise does not necessarily constitute or imply its endorsement, recommendation, or favoring by the United States Government or any agency thereof. The views and opinions of authors expressed herein do not necessarily state or reflect those of the United States Government or any agency thereof. 


\section{DISCLAIMER}

Portions of this document may be illegible in electronic image products. Images are produced from the best available original document. 
The Waste Isolation Pilot Plant (WIPP) will be used for the disposal of transuranic waste from defense programs of the U.S. Department of Energy (DOE). The WIPP facility is located $42 \mathrm{~km}$ east of the town of Carlsbad in southeastern New Mexico. The repository is located $655 \mathrm{~m}$ underground in a Permian bedded salt formation.

In October 1996, the DOE applied to the U.S. Environmental Protection Agency (EPA) for certification of the WIPP's compliance with the relevant radioactive waste disposal standards (40 CFR Part 191) ${ }^{1}$ and criteria (40 CFR Part 194) ${ }^{2}$ that govern post-closure safety. ${ }^{3}$ Demonstrating compliance with these standards and criteria requires an assessment of the long-term performance of the disposal system. For analysis, the universe of all possible occurrences within the 10,000-year regulatory time frame is divided into subsets of similar future occurrences, which are defined as scenarios. ${ }^{\text {a }}$ Because a scenario is defined simply as a subset of futures with similar occurrences, it does not have a specific size. In general, applying the term scenario for larger subsets of futures is useful in discussions of concepts, whereas applying the term scenario for smaller subsets of futures is useful when presenting scenario consequences. This paper is concerned with concepts; other papers in this volume discuss scenario consequences.

The Containment Requirements of 40 CFR Part 191 ( $\square$ 191.13) set limits on the probability that cumulative releases of radionuclides to the accessible environment for 10,000 years after disposal will exceed certain values. The EPA defines the accessible environment to be $\square(1)$ the atmosphere, (2) land surfaces, (3) surface waters, (4) oceans, and (5) all of the lithosphere that is beyond the controlled area $\square$ ( $\square$ 191.12[k]). The definition of the controlled area plays an important role in scenario development, particularly in the consideration of future human actions. For the WIPP, the controlled area consists of a $41-\mathrm{km}^{2}$ area overlying the repository.

The EPA has provided criteria concerning the scope of performance assessments in 40 CFR Part 191 and in the WIPP-specific compliance criteria, 40 CFR Part 194:

\footnotetext{
a Note that scenarios would not necessarily have to be defined as subsets of similar future occurrences, but defining a scenario as a subset of similar futures confers a practical advantage because the consequences of futures falling within one scenario can be calculated with the same model configuration. ${ }^{18}$
} 
- 40 CFR $\square$ 191.13(a) requires performance assessments to consider $\square$ all significant processes and events that may affect the disposal system $\square$

- 40 CFR $\square$ 194.32(e) provides further detail for the WIPP, and states that:

Any compliance application(s) shall include information which:

(1) Identifies all potential processes, events or sequences and combinations of processes and events that may occur during the regulatory time frame and may affect the disposal system;

(2) Identifies the processes, events or sequences and combinations of processes and events included in performance assessments; and

(3) Documents why any processes, events or sequences and combinations of processes and events identified pursuant to paragraph $(\mathrm{e})(1)$ of this section were not included in performance assessment results provided in any compliance application.

Evaluation of the consequences of scenarios begins with the determination of the scenarios to be analyzed. The DOE has determined scenarios through a formal process similar to that proposed by Cranwell et al., and used in preliminary performance assessments for the WIPP. ${ }^{5.6}$ This process has four steps:

(1) FEPs (features, events, and processes) potentially relevant to the WIPP are identified and classified.

(2) Certain FEPs are eliminated according to well-defined screening criteria because they are not important or not relevant to the performance of the WIPP.

(3) Scenarios are formed from the remaining FEPs in the context of regulatory performance criteria.

(4) Scenarios are specified for consequence analysis.

This paper illustrates the DOE's application of this methodology for the Compliance Certification Application (CCA) for the WIPP. ${ }^{3}$ Steps (1) and (2) of the scenario development process are described in Section 2; Steps (3) and (4) are described in Section 3.

Scenario development for a particular disposal concept depends on the purpose of the assessment and the barrier system that isolates the radioactive waste after disposal. For the WIPP, long-term containment of wastes will be provided by a multibarrier system that comprises three principal components: $:^{3}$ 
(i) Engineered barriers (magnesium oxide [MgO] backfill, shaft, drift, and panel seal systems). Waste canisters will be crushed by salt creep relatively soon after the repository is decommissioned; other components of the repository system will evolve gradually, and will provide a barrier function over the regulatory period. In particular, long-term performance of the shaft seal systems, and chemical conditioning provided by the $\mathrm{MgO}$ backfill are important in limiting releases.

(ii) The 600-m thick halite host rock (Salado Formation). This unit has extremely low permeability when undisturbed, and will not provide a pathway for significant contaminant transport to the accessible environment.

(iii) The geologic units underlying and overlying the Salado. Given a breach of the Salado by a future borehole, significant delay and retardation of radionuclides will occur in units overlying or underlying this Formation. The historical focus of the project has been strongly on the Culebra Dolomite Member of the Rustler Formation, which is the most transmissive unit overlying the repository. However, the DOE accounts for additional hydrological units above and below the repository in performance assessment calculations.

\section{IDENTIFICATION AND SCREENING OF FEATURES, EVENTS, AND PROCESSES}

\subsection{Identification of FEPs}

The first step of the scenario development procedure is the identification and classification of FEPs potentially relevant to the performance of the disposal system. In constructing a comprehensive list of FEPs for the WIPP, the DOE followed several avenues of inquiry, including (i) review of FEP lists developed in other disposal programs, (ii) review of WIPP project literature, and (iii) reviews by, and documented meetings with, WIPP project staff, WIPP project stakeholders, ${ }^{b}$ and the EPA. This work is summarized here.

Catalogs of FEPs have been developed in several national radioactive waste disposal programs, as well as internationally. As a checklist for the development of a site-specific FEP list for the WIPP,

\footnotetext{
${ }^{b}$ WIPP project stakeholders contributing to the process included the Enviromental Evaluations Group, the State of New Mexico Attorney General's office, the Southwest Research and Information Center, Citizens for Alternatives to Radioactive Dumping. Concerned Citizens for Nuclear Safety, and members of the public.
} 
the DOE assembled a list of potentially relevant FEPs using a set of nine existing FEP lists developed by different programs for different disposal concepts, including a bedded salt concept (see Table 1). The same set of FEP lists had been used by the Swedish Nuclear Power Inspectorate (SKI) in developing a FEP list in Sweden. ${ }^{7}$ This compilation of FEP lists formed the best documented and most comprehensive checklist available at the time the work was conducted. ${ }^{C}$

This checklist was used as a starting point to derive the comprehensive site-specific CCA FEP list. The following steps were taken:

- To ensure comprehensiveness, other FEPs specific to the WIPP were added to the checklist based on review of key project documents, and examination of the checklist by project participants, stakeholders, and the EPA. ${ }^{16}$ The final checklist is contained in Attachment 1 of Appendix SCR of the CCA.

- The checklist was then substantially restructured, revised, and initially screened, with the number of FEPs reduced to approximately 240 , as follows:

- Duplicate FEPs were eliminated. Duplicate FEPs arose in the checklist because individual FEPs can act in different subsystems. FEPs have a single entry in the CCA FEP list whether they are applicable to several parts of the disposal system or to a single part only.

- FEPs that are not relevant to the WIPP design or inventory were eliminated. Examples include FEPs related to high-level waste, copper canisters, and bentonite backfill.

- FEPs related to engineering design changes were eliminated because they are not relevant to a compliance application based on the DOEワs design for the WIPP.

- FEPs related to constructional, operational, and decommissioning errors were eliminated. The DOE has administrative and quality control procedures to ensure that the WIPP facility will be constructed, operated, and decommissioned properly.

c The Nuclear Energy Agency (NEA) of the Organization for Economic Cooperation and Development (OECD) is in the process of establishing a broadly based international FEP database, consisting of the various national FEP lists. When available, this international database will form a useful tool for future FEP analysis. The CCA FEP list forms part of this international database. 
- Detailed FEPs related to processes in the surface environment were aggregated into a small number of generalized FEPs.

- FEPs related to the containment of hazardous metals, volatile organic compounds (VOCs), and other chemicals that are not regulated by 40 CFR Part 191 were not included on the CCA FEP list.

- Several FEPs were renamed to be consistent with terms used to describe specific WIPP processes.

- Additional detail was added to the FEP list in some areas where it was felt necessary to increase the clarity of the analysis. For example, the single FEP $\square$ dissolution $\square$ was replaced by the FEPs $\square$ deep dissolution, $\square$ पlateral dissolution, $\square$ and $\square$ shallow dissolution, $\square$ all of which represent distinct processes at the WIPP.

- FEPs were reclassified under the major headings Natural, Waste- and RepositoryInduced, and Human-Initiated, with each of these major headings being given consistent subheadings according to a top-down structured breakdown of knowledge about the WIPP (see Table 2).

- Finally, as part of the revisions to produce the final CCA FEP list, the draft CCA list was reviewed by project staff, stakeholders, and the EPA, as part of the DOEロs efforts to ensure comprehensiveness and clarity of the final list. The CCA FEP list is included in Chapter 6 and Appendix SCR of the CCA. ${ }^{3}$

\subsection{Criteria for Screening FEPs and Categorizing Retained FEPs}

The purpose of FEP screening was to identify those FEPs on the CCA FEP list that should be accounted for in performance assessment calculations, and those FEPs that need not be considered further. The DOE $\square$ s process of removing FEPs from consideration in performance assessment calculations involved the structured application of three screening criteria. The criteria used to screen out FEPs were explicit regulatory exclusion (SO-R), probability (SO-P), and/or consequence (SO-C). As discussed in Section 2.2.1, all three criteria are derived from regulatory requirements. FEPs not screened as SO-R, SO-P, or SO-C were retained for inclusion in performance assessment calculations and were classified as undisturbed performance (UP) or disturbed performance (DP) 
FEPs. These screening criteria and FEP classifiers are discussed in this section, and FEP screening is briefly discussed in Sections $2.3-2.5$ under the headings Natural FEPs, Waste- and RepositoryInduced FEPs, and Human-Initiated FEPs. Detailed screening discussions for FEPs are not presented here, but are contained in Appendix SCR of the CCA. This Appendix is several hundreds of pages in length, and is supported by numerous WIPP project references.

2.2.1 Elimination of FEPs based on regulation (SO-R), probability (SO-P), and/or consequence (SO-C)

Regulation (SO-R). The EPA provides specific FEP screening criteria in 40 CFR Part 191 and 40 CFR Part 194. These screening criteria represent screening decisions made by the EPA. That is, in the process of developing and demonstrating the feasibility of the 40 CFR Part 191 standard and the 40 CFR Part 194 criteria, the EPA considered and made conclusions on the relevance, consequence, and/or probability of occurrence of particular FEPs and, in so doing, allowed for some FEPs to be eliminated from consideration. Section 2.5 describes the regulatory screening criteria that pertain to the human-initiated events and processes that need to be considered.

Probability of occurrence of a FEP leading to significant release of radionuclides (SO-P). Lowprobability events can be excluded on the basis of the criterion provided in 40 CFR $\square$ 194.32(d), which states that $\square$ performance assessments need not consider processes and events that have less than one chance in 10,000 of occurring over 10,000 years. $\square$ In practice, for most FEPs screened out on the basis of low probability of occurrence, it has not been possible for the DOE to estimate a meaningful quantitative probability. In the absence of quantitative probability estimates, a qualitative argument was provided in the CCA.

Potential consequences associated with the occurrence of the FEPs (SO-C). The DOE recognized two uses for this criterion:

(1) FEPs can be eliminated from performance assessment calculations on the basis of insignificant consequence. Consequence can refer to effects on the repository or site or to radiological consequence. In particular, 40 CFR $\square$ 194.34(a) states that $\square$ The results of performance assessments shall be assembled into complementary, cumulative distribution functions (CCDFs) that represent the probability of exceeding various levels of cumulative release caused by all significant processes and events. $\square$ (emphasis added). The DOE has 
omitted events and processes from performance assessment calculations where there is a reasonable expectation that the remaining probability distribution of cumulative releases would not be significantly changed by such omissions.

(2) FEPs that are potentially beneficial to subsystem performance may be eliminated from performance assessment calculations if necessary to simplify the analysis. This argument has been used when there is uncertainty as to exactly how the FEP should be incorporated into assessment calculations or when incorporation would incur unreasonable difficulties.

In some cases the effects of the occurrence of a particular event or process, although not necessarily insignificant, can be shown to lie within the range of uncertainty of another FEP already accounted for in the performance assessment calculations. In such cases the event or process may be considered to be included in performance assessment calculations implicitly, within the range of uncertainty associated with the included FEP.

The distinctions between the SO-R, SO-P, and SO-C screening classifications are summarized in Figure 1. Although some FEPs could be eliminated from performance assessment calculations on the basis of more than one criterion, the most practical screening criterion was used for classification. In particular, a regulatory screening classification was used in preference to a probability or a consequence screening classification, as illustrated in Figure 1. FEPs that have not been screened out based on any one of the three criteria have been accounted for in performance assessment calculations.

\subsubsection{Undisturbed Performance (UP) FEPs}

FEPs classified as UP are accounted for in calculations of undisturbed performance of the disposal system (see Section 3.1). Undisturbed performance is defined in 40 CFR 191.12 as Dthe predicted behavior of a disposal system, including consideration of the uncertainties in predicted behavior, if the disposal system is not disrupted by human intrusion or the occurrence of unlikely natural events. $\square$ The UP FEPs are accounted for in evaluating compliance with the individual dose criterion in 40 CFR $\square 191.15$ and the groundwater protection requirements in 40 CFR $\square$ 191.24. The UP

FEPs are also accounted for in the performance assessment calculations to evaluate compliance with the Containment Requirements in 40 CFR $\square 191.13$. 


\subsubsection{Disturbed Performance (DP) FEPs}

FEPs classified as DP are accounted for only in the assessment calculations for disturbed performance, required to evaluate compliance with the Containment Requirements (see Section 3.2). The DP FEPs that remain following the screening process relate to the potential disruptive effects of future drilling and mining events in the WIPP controlled area.

\subsection{Screening of Natural FEPs}

Consistent with 40 CFR $\square$ 194.32(d), the DOE screened out several natural FEPs from performance assessment calculations on the basis of a low probability of occurrence at or near the WIPP site. In particular, natural events for which there is no evidence of occurrence within the Delaware Basin were screened out on this basis. In this analysis, the probabilities of occurrence of these events was assumed to be zero. Quantitative, nonzero probabilities for such events, based on numbers of occurrences, cannot be ascribed without considering regions much larger than the Delaware Basin, thus neglecting established geological understanding of the events and processes that occur within particular geographical provinces. No disruptive natural FEPs that could result in the creation of new pathways or significant alteration of existing pathways have a probability of greater than $10^{-4}$ of occurring during the 10,000-year regulatory time frame. For the WIPP setting, this is also true over much longer periods $\left(10^{5}-10^{6}\right.$ years $)$.

In considering the overall geological setting of the Delaware Basin, the DOE eliminated many FEPs from performance assessment calculations on the basis of low consequence. Events and processes that have had little effect on the characteristics of the region in the past are expected to be of low consequence for the period of regulatory interest.

\subsection{Screening of Waste- and Repository-Induced FEPs}

The waste- and repository-induced FEPs are those that relate specifically to the waste material, waste containers, shaft seals, MgO backfill, panel closures, repository structures, and investigation boreholes. All FEPs related to radionuclide chemistry and radionuclide migration have been included in this category. FEPs related to radionuclide transport resulting from future borehole intersections of the WIPP excavation have also been included in this category.

The DOE screened out many FEPs in this category on the basis of low consequence to the performance of the disposal system. For example, the DOE has shown that the heat generated by 
radioactive decay of the emplaced $\mathrm{RH}$ - and $\mathrm{CH}$-TRU waste will not result in significant thermal convection, thermal stresses and strains, or thermally induced chemical perturbations within the disposal system. Also, hydration of the emplaced concrete seals and $\mathrm{MgO}$ chemical conditioner will be exothermic, but the DOE has shown that the heat generated will not have a significant effect on the performance of the disposal system.

Other waste- and repository-induced FEPs were eliminated from performance assessment calculations on the basis of beneficial effect on the performance of the disposal system, when necessary to simplify the analysis.

Waste- and repository-induced FEPs eliminated on the basis of low probability of occurrence over 10,000 years are generally those for which no mechanisms have been identified that could result in their occurrence within the disposal system. Such FEPs include explosions resulting from nuclear criticality, and the development of large-scale reduction-oxidation fronts.

\subsection{Screening of Human-Initiated Events and Processes}

Assessments of compliance with the Containment Requirements in 40 CFR $\square 191.13$ require consideration of $\square$ all significant processes and events $\square$ including human-initiated FEPs. For the WIPP, human-initiated events and processes drive the identification of disturbed performance scenarios.

The scope of performance assessments is clarified with respect to human-initiated events and processes in 40 CFR $\square$ 194.32. At 40 CFR $\square$ 194.32(a) the EPA states that $\square$ Performance assessments shall consider natural processes and events, mining, deep drilling, and shallow drilling that may affect the disposal system during the regulatory time frame. $\square$ Thus, performance assessments must include consideration of human-initiated FEPs relating to mining and drilling activities that might take place during the 10,000-year regulatory time frame. In particular, performance assessments must consider the potential effects of such activities that might take place within the controlled area at a time when institutional controls cannot be assumed to eliminate completely the possibility of human intrusion.

Further criteria concerning the scope of performance assessments are provided at 40 CFR ¿ 194.32(c): 
Performance assessments shall include an analysis of the effects on the disposal system of any activities that occur in the vicinity of the disposal system prior to disposal and are expected to occur in the vicinity of the disposal system soon after disposal. Such activities shall include, but shall not be limited to, existing boreholes and the development of any existing leases that can be reasonably expected to be developed in the near future, including boreholes and leases that may be used for fluid injection activities.

Thus, performance assessments must include consideration of all human-initiated FEPs relating to activities that have taken place or are reasonably expected to take place outside the controlled area in the near future.

In order to implement the criteria in 40 CFR $\square 194.32$ relating to the scope of performance assessments, the DOE divided human activities into three categories. Distinctions are made between (1) human activities that are currently taking place and those that took place prior to the submission of the CCA, (2) human activities that might be initiated in the near future after submission of the CCA, and (3) human activities that might be initiated after repository closure. The first two categories of FEPs are considered under undisturbed performance, and FEPs in the third category lead to disturbed performance conditions.

(1) Historical and current human activities include resource extraction activities that have historically taken place and are currently taking place outside the controlled area. These activities are of potential significance insofar as they could affect geological, hydrological, or geochemical conditions within or outside the disposal system. Current human activities taking place within the controlled area are essentially those associated with development of the WIPP repository. Historical activities include existing boreholes.

(2) Near-future human activities include resource extraction activities that may be expected to occur outside the controlled area based on existing plans and leases. Thus, the near future includes the expected lives of existing mines and oil and gas fields, and the expected lives of new mines and oil and gas fields that the DOE anticipates will be developed based on existing plans and leases. These activities are of potential significance insofar as they could affect geological, hydrological, or geochemical conditions within or outside the disposal system. The only human activities that are expected to occur within the controlled area in the near future are those associated with development of the WIPP repository. The DOE assumes that any activity that is expected to be initiated in the near future, based on existing 
plans and leases, will be initiated prior to repository closure. Activities initiated prior to repository closure are assumed to continue for their expected economic lifetime.

(3) Future human activities include activities that might be initiated within or outside the controlled area after repository closure. This includes drilling and mining for resources within the disposal system at a time when institutional controls cannot be assumed to eliminate completely the possibility of such activities. Future human activities could influence the transport of contaminants within and outside the disposal system by directly removing waste from the disposal system, or altering the geological, hydrological, or geochemical conditions within or outside the disposal system.

For the WIPP, performance assessments must consider the potential effects of historical, current, near-future, and future human activities on the performance of the disposal system. The EPA requires that performance assessments $\square$ shall assume that the characteristics of the future remain what they are at the time the compliance application is prepared. $\square$ This criterion was applied to eliminate the following human-initiated FEPs from performance assessment calculations:

- Drilling associated with geothermal energy production, hydrocarbon storage, and archaeological investigations.

- Excavation àctivities associated with tunneling and construction of underground facilities (for example, storage, disposal, and accommodation).

- Changes in land use.

- Anthropogenic climate change.

- Changes in agricultural practices.

- Demographic change, urban developments, and technological developments.

\subsubsection{Screening of historical, current, and near-future human activities}

The observational data obtained as part of WIPP site characterization reflect any effects of historical and current human activities in the vicinity of the WIPP, such as groundwater extraction and oil and gas production. Historical and current human activities were either modeled or found to be of low consequence to long-term performance. 
Historical, current, and near-future human activities could affect WIPP site characteristics subsequent to the submission of the CCA, and could influence the performance of the disposal system. The hydrogeological impacts of historical, current and near-future potash mining outside the controlled area were accounted for in calculations of the undisturbed performance of the disposal system. Other human-initiated FEPs expected to occur in the Delaware Basin were eliminated from assessment calculations on the basis of low consequence to the performance of the disposal system.

\title{
2.5.2 Screening of future human activities
}

Performance assessments must consider the effects of future human activities on the performance of the disposal system. The EPA has provided criteria relating to future human activities in $40 \mathrm{CFR}$ 194.32(a), which limits the scope of consideration of future human actions in performance assessments to mining and drilling.

Criteria concerning future mining: The EPA provides additional criteria concerning the type of future mining that should be considered by the DOE in 40 CFR $\square$ 194.32(b):

\begin{abstract}
Assessments of mining effects may be limited to changes in the hydraulic conductivity of the hydrogeologic units of the disposal system from excavation mining for natural resources. Mining shall be assumed to occur with a one in 100 probability in each century of the regulatory time frame. Performance assessments shall assume that mineral deposits of those resources, similar in quality and type to those resources currently extracted from the Delaware Basin, will be completely removed from the controlled area during the century in which such mining is randomly calculated to occur. Complete removal of such mineral resources shall be assumed to occur only once during the regulatory time frame.
\end{abstract}

Thus, consideration of future mining may be limited to mining within the controlled area at the locations of resources that are similar in quality and type to those currently extracted from the Delaware Basin. Potash is the only resource that has been identified within the controlled area in quality similar to that currently mined from underground deposits elsewhere in the Delaware Basin. Within the controlled area, the McNutt Member of the Salado Formation provides the only potash of appropriate quality to justify mining. The hydrogeological impacts of future potash mining within the controlled area were accounted for in calculations of the disturbed performance of the disposal system. Consistent with 40 CFR $\square 194.32$ (b), all economically recoverable resources in the vicinity of the disposal system (outside the controlled area) were assumed to be extracted in the near future. Criteria concerning future drilling: With respect to consideration of future drilling, in the preamble to 40 CFR Part 194, the EPA Ireasoned that while the resources drilled for today may not be the 
same as those drilled for in the future, the present rates at which these boreholes are drilled can nonetheless provide an estimate of the future rate at which boreholes will be drilled. $\square$ Criteria concerning the consideration of future deep and shallow drilling ${ }^{d}$ in performance assessments are provided in $40 \mathrm{CFR} \square$ 194.33. These criteria require that, to calculate future drilling rates, the DOE should examine the historical rate of drilling for resources in the Delaware Basin. Historical drilling for purposes other than resource exploration and recovery (such as WIPP site investigation) need not be considered in determining future drilling rates.

In particular, in calculating the frequency of future deep drilling, 40 CFR $\square$ 194.33(b)(3)(i) states that the DOE should $\square$ Identify deep drilling that has occurred for each resource in the Delaware Basin over the past 100 years prior to the time at which a compliance application is prepared. $\square$ Oil and gas are the only known resources below 655 meters $(2,150$ feet $)$ that have been exploited over the past 100 years in the Delaware Basin. However, some potash and sulfur exploration boreholes have been drilled in the Delaware Basin to depths in excess of 655 meters $(2,150$ feet) below the surface relative to where the drilling occurred. Thus, consistent with 40 CFR $\square$ 194.33(b)(3)(i), the DOE has used the historical record of deep drilling associated with oil, gas, potash and sulfur exploration, and oil and gas exploitation in the Delaware Basin in calculations to determine the rate of deep drilling within the controlled area and throughout the basin in the future. Deep drilling may occur within the controlled area after the end of the period of active institutional control (100 years after disposal).

In calculating the frequency of future shallow drilling, 40 CFR $\square$ 194.33(b)(4)(i) states that the DOE should DIdentify shallow drilling that has occurred for each resource in the Delaware Basin over the past 100 years prior to the time at which a compliance application is prepared. $\square$ An additional criterion with respect to the calculation of future shallow drilling rates is provided in $40 \mathrm{CFR}$ $\square$ 194.33(b)(4)(iii): In considering the historical rate of all shallow drilling, the Department may, if justified, consider only the historical rate of shallow drilling for resources of similar type and quality to those in the controlled area.

d The EPA defined two types of drilling in 40 CFR 194.2: deep drilling is defined as _. drilling events in the Delaware Basin that reach or exceed a depth of 2.150 feet below the surface relative to where such drilling occurred-; shallow drilling is defined as drilling events in the Delaware Basin that do not reach a depth of 2,150 feet below the surface relative to where such drilling occurred:- 
As an example of the use of the criterion in 40 CFR $\square$ 194.33(b)(4)(iii), the EPA states in the preamble to 40 CFR Part 194 that Dif only non-potable water can be found within the controlled area, then the rate of drilling for water may be set equal to the historical rate of drilling for nonpotable water in the Delaware Basin over the past 100 years. $\square$ Thus, the DOE may limit the rate of future shallow drilling based on a determination of the potential resources in the controlled area. Shallow drilling associated with exploration and extraction of water, potash, sulfur, oil, and gas has taken place in the Delaware Basin over the past 100 years. However, of these resources, only water and potash are present at shallow depths (less than 655 meters [2,150 feet] below the surface) within the controlled area. Thus, consistent with 40 CFR 1 194.33(b)(4), the DOE used the historical record of shallow drilling associated with water and potash exploitation in the Delaware Basin in calculations to determine the rate of shallow drilling within the controlled area.

The EPA also provides a criterion in 40 CFR $\square 194.33$ (d) concerning the use of future boreholes subsequent to drilling: $\square$ With respect to future drilling events, performance assessments need not analyze the effects of techniques used for resource recovery subsequent to the drilling of the borehole. Thus, performance assessments need not consider the effects of techniques used for resource extraction and recovery, that would occur subsequent to the drilling of a borehole in the future.

The EPA provides an additional criterion that limits the severity of human intrusion scenarios that must be considered in performance assessments. In 40 CFR $\square$ 194.33(b)(1) the EPA states that $\square$ Inadvertent and intermittent intrusion by drilling for resources (other than those resources provided by the waste in the disposal system or engineered barriers designed to isolate such waste) is the most severe human intrusion scenario. $\square$ Thus, human intrusion scenarios involving deliberate intrusion need not be considered in performance assessments.

Summary: Future human-initiated FEPs accounted for in performance assessment calculations for the WIPP are those associated with mining and deep drilling within the controlled area at a time when institutional controls cannot be assumed to eliminate completely the possibility of such activities. All other future human-initiated FEPs, if not eliminated from performance assessment calculations based on regulation, have been eliminated based on low consequence or low probability. For example, the effects of future shallow drilling within the controlled area have been eliminated 
from performance assessment calculations on the basis of low consequence to the performance of the disposal system.

\section{SCENARIO DEVELOPMENT AND SELECTION}

This section addresses the formation of scenarios from FEPs that have been retained for performance assessment calculations, and introduces the specification of scenarios for consequence analysis. Scenarios are formed from combinations of FEPs that survive the screening process. The language and requirements of the regulations have a significant influence on the scenario development process. For example, as noted in Section 2.2, the EPA has defined undisturbed performance to mean Dthe predicted behavior of a disposal system, including consideration of the uncertainties in predicted behavior, if the disposal system is not disrupted by human intrusion or the occurrence of unlikely natural events.

Logic diagrams can be used to illustrate the formation of scenarios for consequence analysis (Figure 2). Each scenario shown in Figure 2 is defined by a combination of occurrence and nonoccurrence of all potentially disruptive FEPs. Disruptive FEPs are defined as those FEPs that result in the creation of new pathways, or significant alteration of existing pathways, for fluid flow and, potentially, radionuclide transport within the disposal system. Each of these scenarios also contains a set of features and nondisruptive FEPs that remain after FEP screening. As shown in Figure 2, undisturbed performance and disturbed performance scenarios are considered in consequence modeling for the WIPP performance assessment. Important aspects of undisturbed and disturbed performance are summarized in this section.

\subsection{Undisturbed Performance}

No potentially disruptive natural FEPs are likely to occur during the regulatory time frame. All of the natural FEPs retained for scenario construction are nondisruptive and, with the exception of the FEP $\square$ brine reservoirs $\sqsupseteq$, are considered as part of undisturbed performance. Brine reservoirs may be present in the Castile Formation, which underlies the Salado and, although they are not relevant to undisturbed performance, brine reservoirs could play a role in certain disturbed performance scenarios that account for the potential effects of future deep drilling within the controlled area (see Section 3.2). 
Similarly, the majority of waste- and repository-induced FEPs retained for scenario construction are considered as part of the undisturbed performance scenario. Again, the only exceptions are four FEPs exclusively related to the potential effects of future deep drilling within the controlled area.

Several FEPs relating to human activities that are retained for scenario construction are not disruptive to the disposal system and are, therefore, considered in undisturbed performance. For example, potash mining outside the controlled area does not constitute a disruption of the disposal system. However, the retained future human-initiated FEPs occurring inside the controlled area do present potential disruptions to the disposal system and have been used to develop disturbedperformance scenarios.

In total, 67 undisturbed performance FEPs have been identified (Table 3). Among the most significant FEPs that will affect the undisturbed performance within the disposal system are excavation-induced fracturing, gas generation, salt creep, and $\mathrm{MgO}$ backfill in the disposal rooms:

- The excavation of the repository and the consequent changes in the stress field in the rock surrounding the excavated opening will create a disturbed rock zone (DRZ) immediately adjacent to excavated openings. The DRZ will exhibit mechanical and hydrological properties different than those of the intact rock.

- Organic material in the waste may degrade because of microbial activity, and brine will corrode metals in the waste and waste containers. Gas generation from either or both processes may result in pressures sufficient to both maintain or develop fractures and change the fluid flow pattern around the waste disposal region.

- At the repository depth, salt creep will tend to heal fractures and reduce the permeability of the $\mathrm{DRZ}$ and the crushed salt component of the long-term shaft seals to near that of the host rock salt.

- $\mathrm{MgO}$ backfill to be emplaced in the disposal rooms will react with carbon dioxide $\left(\mathrm{CO}_{2}\right)$ and maintain mildly alkaline conditions. Corrosion of metals in the waste and waste containers will maintain reducing conditions. These effects will control radionuclide solubility.

Radionuclides can become mobile as a result of waste dissolution and colloid generation following brine flow into the disposal rooms. Colloids may be generated from the waste (humics, mineral 
fragments, and actinide intrinsic colloids) or from other sources (humics, mineral fragments, and microbes).

Conceptually, there are several pathways for radionuclide transport within the undisturbed disposal system that may result in releases to the accessible environment (Figure 3 ). Contaminated brine may move away from the waste-disposal panels if pressure within the panels is elevated by the generation of gas from corrosion or microbial degradation. Radionuclide transport may occur laterally, through the anhydrite interbeds toward the subsurface boundary of the accessible environment in the Salado, or through access drifts or anhydrite interbeds, primarily Marker Bed 139 (MB139), to the base of the shafts. In the latter case, if the pressure gradient between the panels and overlying strata is sufficient, then contaminated brine may move up the shafts. As a result, radionuclides may be transported directly to the ground surface, or they may be transported laterally away from the shafts, through permeable strata (such as the Culebra Member of the Rustler Formation), toward the subsurface boundary of the accessible environment. These conceptual pathways are shown in Figure 3:

\subsection{Disturbed Performance}

Assessments for compliance with 40 CFR $\square 191.13$ need to consider the potential effects of future disruptive natural and human-initiated FEPs on the performance of the disposal system. No potentially disruptive natural FEPs are considered to be sufficiently likely to require inclusion in analyses of either undisturbed or disturbed performance. The only future human-initiated FEPs retained after FEP screening were those associated with mining and deep drilling (but not the subsequent use of a borehole) within the controlled area at a time when institutional controls cannot be assumed to eliminate the possibility of such activities. In total, 21 disturbed performance FEPs associated with future mining and deep drilling were identified (Table 4).

For evaluation of the consequences of disturbed performance, the DOE defined the mining scenario, $\mathrm{M}$, the deep drilling scenario, $\mathrm{E}$, and a mining and drilling scenario, ME. These scenarios are described in the following sections.

\subsubsection{The disturbed performance mining scenario $(M)$}

The disturbed performance mining scenario, $\mathrm{M}$, involves future mining within the controlled area. Consistent with the criteria stated by the EPA in 40 CFR $\square 194.32$ (b), for performance assessment 
calculations, the effects of potential future mining within the controlled area are limited to changes in hydraulic conductivity of the Culebra that result from subsidence. Radionuclide transport may be affected in the $M$ scenario if a head gradient between the waste-disposal panels and the Culebra causes brine contaminated with radionuclides to move from the waste-disposal panels to the base of the shafts and up the shafts to the Culebra. The changes in the Culebra transmissivity field may affect the rate and direction of radionuclide transport within the Culebra. Features of the M scenario are illustrated in Figure 4.

The three disturbed performance FEPs labeled M in Table 4 relate to the occurrence and effects of future mining. The modeling system used for the $M$ scenario is similar to that developed for the undisturbed performance scenario, but with a modified Culebra transmissivity field within the controlled area to account for the effects of mining.

\subsubsection{The disturbed performance deep drilling scenario $(E)$}

The disturbed performance deep drilling scenario, E, involves at least one deep drilling event that intersects the waste disposal region. The EPA provides criteria concerning analysis of the consequences of future drilling events in performance assessments in 40 CFR $\square$ 194.33(c):

Performance assessments shall document that in analyzing the consequences of drilling events, the"Department assumed that:

(1) Future drilling practices and technology will remain consistent with practices in the Delaware Basin at the time a compliance application is prepared. Such future drilling practices shall include, but shall not be limited to: the types and amounts of drilling fluids; borehole depths, diameters, and seals; and the fraction of such boreholes that are sealed by humans; and

(2) Natural processes will degrade or otherwise affect the capability of boreholes to transmit fluids over the regulatory time frame.

Consistent with these criteria, there are several pathways for radionuclides to reach the accessible environment in the E scenario. During the period before any deep drilling intersects the waste, potential release pathways are identical to those in the undisturbed performance scenario.

If a borehole intersects the waste in the disposal rooms, releases to the accessible environment may occur as material entrained in the circulating drilling fluid is brought to the surface. Particulate waste brought to the surface may include cuttings, cavings, and spallings. Cuttings are the materials cut by the drill bit as it passes through waste. Cavings are the materials eroded by the drilling fluid 
in the annulus around the drill bit. Spallings are the materials that may be forced into the circulating drilling fluid if there is sufficient pressure in the waste disposal panels. During drilling, contaminated brine may flow up the borehole and reach the surface, depending on fluid pressure within the waste disposal panels.

When abandoned, the borehole is assumed to be plugged in a manner consistent with current practice in the Delaware Basin. An abandoned intrusion borehole with degraded casing and/or plugs may provide a pathway for fluid flow and contaminant transport from the intersected waste panel to the ground surface if the fluid pressure within the panel is sufficiently greater than hydrostatic. Additionally, if brine flows through the borehole to overlying units, such as the Culebra, it may carry dissolved and colloidal actinides that can then be transported laterally to the accessible environment by natural groundwater flow in the overlying units.

The units intersected by an intrusion borehole may provide sources for brine flow to a waste panel during or after drilling. For example, in the northern Delaware Basin, the Castile, which underlies the Salado, contains isolated volumes of brine at fluid pressures greater than hydrostatic. Such a borehole could provide a connection for brine flow from the Castile to the waste panel, thus increasing fluid pressure and brine volume in the waste panel.

Also, a borehole that is drilled through a disposal room pillar, but does not intersect waste, could penetrate the brine reservoir underlying the waste disposal region. Such an event would, to some extent, depressurize the brine reservoir, and thus would affect the consequences of any subsequent intersections of the reservoir. The possibility for boreholes that do not penetrate the waste to depressurize a brine reservoir underlying the waste disposal region is accounted for in the consequence analysis of the WIPP.

The DOE has distinguished two types of deep drilling events by whether or not the borehole intersects a Castile brine reservoir. A borehole that intersects a waste disposal panel and penetrates a Castile brine reservoir has been designated an $\mathrm{E} 1$ event. The 18 disturbed performance FEPs labeled E1 in Table 4 relate to the occurrence and effects of an E1 drilling event. A borehole that intersects a waste panel but does not penetrate a Castile brine reservoir has been designated an E2 event. The 18 disturbed performance FEPs labeled E2 in Table 4 relate to the occurrence and effects of an E2 drilling event. 
In order to evaluate the consequences of future deep drilling, the DOE has divided the E scenario into three drilling subscenarios, E1, E2 and E1E2, distinguished by the number of E1 and E2 drilling events that are assumed to occur in the regulatory time frame. These subscenarios are described in order of increasing complexity in the following sections.

The E2 Scenario: The E2 scenario is the simplest scenario for inadvertent human intrusion into a waste disposal panel. In this scenario, a panel is penetrated by a drill bit; cuttings, cavings, spallings, and brine flow releases may occur; and brine flow may occur in the borehole after it is plugged and abandoned. Sources for brine that may contribute to long-term flow up the abandoned borehole are the Salado or, under certain conditions, the units above the Salado. An E2 scenario may involve more than one E2 drilling event. Features of the E2 scenario are illustrated in Figure 5. A modeling system has been developed to evaluate the consequences of an E2 scenario during which single or multiple E2 events occur.

The E1 Scenario: Any scenario with a single inadvertent penetration of a waste panel that also penetrates a Castile brine reservoir is called E1. Features of this scenario are illustrated in Figure 6. Sources of brine in the $\mathrm{E} 1$ scenario are the brine reservoir, the Salado and, under certain conditions, the units above the Salado. However, the brine reservoir is conceptually the dominant source of brine in this scenario. The model configuration developed for the El scenario is used to evaluate the consequences of futures that have only one $\mathrm{E} 1$ event per panel. A future during which more than one $\mathrm{E} 1$ event occurs in a single panel is described as an E1E2 scenario.

The E1E2 Scenario: The E1E2 scenario is defined as all futures that have multiple penetrations of a waste panel of which at least one intrusion is an El type. One case of this scenario, with a single E1 event and a single E2 event penetrating the same panel, is illustrated in Figure 7. However, the E1E2 scenario can include many possible combinations of intrusion times, locations, and types of event (E1 or E2). The sources of brine in this scenario are those listed for the E1 scenario, and multiple E1-type sources may be present. The E1E2 scenario potentially has a flow path not present in the E1 or E2 scenarios: flow from an E1 borehole through the waste to another borehole. This flow path has the potential to (i) bring large quantities of brine in direct contact with waste and (ii) provide a less restrictive path for this brine to flow to the units above the Salado (via multiple boreholes) compared to either the $\mathrm{E} 1$ or $\mathrm{E} 2$ individual scenarios. Both the presence of brine reservoirs and the potential for flow through the waste to other boreholes make this scenario different 
in terms of potential consequences from combinations of E2 boreholes. The extent to which flow occurs between boreholes, as estimated by modeling, determines whether combinations of $\mathrm{E} 1$ and E2 boreholes at specific locations in the repository should be treated as E1E2 scenarios or as independent E1 and E2 scenarios in the consequence analysis. Because of the number of possible combinations of drilling events, the modeling configuration for the E1E2 scenario differs in significant ways from the model configuration used for evaluating E1 and E2 scenarios.

\subsubsection{The disturbed performance mining and deep drilling scenario (ME)}

Mining in the WIPP site (the M scenario) and deep drilling (the $\mathrm{E}$ scenario) may both occur in the future. The DOE calls a future in which both of these events occur the ME scenario. The occurrence of both mining and deep drilling does not create processes in addition to those already described separately for the $\mathrm{M}$ and $\mathrm{E}$ scenarios. For example, the occurrence of mining does not influence any of the interactions between deep boreholes and the repository or brine reservoirs. As well, the occurrence of drilling does not impact the effects of mining on Culebra hydrogeology. The difference between the $\mathrm{M}$ and $\mathrm{E}$ scenarios considered separately and the ME scenario is that the combination of borehole transport to the Culebra $(E)$ and a transmissivity field impacted by mining (M) may result in more rapid transport of radionuclides to the accessible environment. For example, because the $M$ scenario does not include drilling, the only pathway for radionuclides to reach the Culebra is up the sealed shafts. For clarity in describing computational results, the ME scenario was subdivided in the CCA according to the types of deep drilling subscenarios into the ME1 scenario ( $M$ and E1), the ME2 scenario ( $M$ and E2), and the ME1E2 scenario ( $M$ and E1E2).

The system used for modeling flow and transport in the Culebra for the ME scenario is similar to that used for the E scenario. However, in the ME scenario the Culebra transmissivity field is modified to account for the effects of mining within the controlled area.

\subsection{Scenarios Retained for Performance Assessment}

The FEPs that remain after screening are accounted for in performance assessment calculations either through explicit representation in the equations that form the mathematical models or implicitly through the specification of parameter values used as input to the performance assessment codes. Tables 3 and 4 list the FEPs accounted for in calculations of disposal system performance under undisturbed and disturbed conditions, respectively. In these tables, FEPs treated through explicit 
representation in the equations on which the performance assessment codes are based are designated $\mathrm{C}$ (for code), and FEPs treated through the specification of parameter values are designated $\mathrm{P}$ (for parameter). FEPs designated $\mathrm{C}$ generally require specification of parameter values as well. In some cases, a submodel is used to generate parameter values that are necessary for the solution of the basic governing equations. FEPs incorporated by such submodels are generally denoted $\mathrm{P}$. For example, a model of creep closure of the disposal rooms has been used to generate values of room porosity for use in the performance assessment code BRAGFLO, and this creep closure model accounts for several FEPs designated $P$.

The modeling systems used to evaluate the consequences of the undisturbed and disturbed performance scenarios are discussed in other papers in this volume. ${ }^{18,19}$ For consequence analysis, the scenarios and subscenarios described here were further subdivided into modeling scenarios (termed $S_{i}$ ). The modeling scenarios are distinguished by, for example, the time of occurrence of disruptive events, and are generated by probabilistic sampling of selected processes and events.

\subsection{Conclusions}

A robust and tested methodology has been applied for identifying and screening FEPs, and for combining FEPs to form scenarios for consequence analysis. This paper has described the methodology and its application to the WIPP. The methodology consists of (i) identifying and classifying FEPs, (ii) screening FEPs according to well-defined criteria, (iii) forming scenarios (combinations of FEPs) in the context of regulatory performance criteria, and (iv) specification of scenarios for consequence analysis.

The procedure used to derive and build confidence in the comprehensiveness and relevance of the CCA FEP list included the use of available international experience in assembling FEP lists, combined with extensive documented review of the WIPP FEP list within the project, and by stakeholders and the EPA. FEPs were eliminated from performance assessment calculations using criteria defined by regulation, including explicit regulatory exclusion, probability of occurrence over 10,000 years, and/or consequence to the performance of the disposal system. The development and screening of a comprehensive FEP list provides assurance that the identification of significant processes and events is complete, that potential interactions between FEPs are not overlooked, and that responses to possible questions are available and well documented. 
The FEPs remaining after screening were combined to form two main scenarios: undisturbed performance and disturbed performance. Two means of accounting for screened-in FEPs were identified: through explicit representation in the equations of the assessment codes, or through parameter values used by the codes. The undisturbed performance scenario formed the basis of calculations to evaluate compliance with the EPA $\amalg$ s Individual Dose (40 CFR $\square 191.15$ ) and Groundwater Protection (40 CFR 1 191.24) criteria, and accounted for all natural and waste- and repository induced FEPs that survived the screening process. Disturbed performance scenarios, along with the undisturbed performance scenario, formed the basis of calculations to evaluate compliance with the EPA $\square$ s Containment Requirements (40 CFR $\square$ 191.13). The disturbed performance scenarios accounted for future human-initiated events and processes, which have an uncertain probability of occurrence, in addition to the undisturbed performance FEPs.

The scenario development work formed an important focus of the review of the CCA by the EPA and by project stakeholders. This work has stood up well to the scrutiny received. Review did not lead to the identification of any fundamentally new FEPs or scenarios, but did lead to the introduction of greater detail in the analysis of certain human-initiated FEPs and in the consequence modeling of disturbed performance scenarios, and to the development of more comprehensive, clearer and more detailed screening documentation. The EPA's Certification Decision of May 18, $1998,{ }^{20}$ which approved disposal of radioactive wastes at the WIPP, shows that the EPA has accepted the DOE's scenario development methodology and its site-specific application as part of the performance assessment for the WIPP CCA.

When the WIPP opened in 1999, it became the world's first specially mined deep geologic disposal system for long-lived radioactive wastes. In no other country is a similar type of repository due to open for at least another decade. The techniques and approaches used within the WIPP project deserve close examination by other disposal projects as they design their performance assessment and site characterization programs, and move toward licensing.

\section{ACKNOWLEDGMENTS}

This work has been performed by the United States Department of Energy under Contract DE-AC0494-AL8500 with Sandia National Laboratories (SNL), and Contract AP-2278 between Galson Sciences Limited and SNL. SNL is operated by Sandia Corporation, a Lockheed Martin Company. 


\section{REFERENCES}

1. EPA (Environmental Protection Agency). 1993. $\square 40$ CFR Part 191: Environmental Radiation Protection Standards for the Management and Disposal of Spent Nuclear Fuel, High-Level and Transuranic Radioactive Wastes; Final Rule. $\square$ Federal Register, Vol. 58, No. 242, pp. $66398 \square 66416$, December 20, 1993. Office of Radiation and Indoor Air, Washington, D.C.

2. EPA (Environmental Protection Agency), 1996. $\square 40$ CFR Part 194: Criteria for the Certification and Re-Certification of the Waste Isolation Pilot Plant $\square$ s Compliance with the 40 CFR Part 191 Disposal Regulations; Final Rule. $\square$ Federal Register, Vol. 61, No. 28, pp. 5224 - 5245, February 9, 1996. Office of Radiation and Indoor Air, Washington, D.C.

3. DOE (Department of Energy). 1996. Title 40 CFR Part 19I Compliance Certification Application for the Waste Isolation Pilot Plant. DOE/CAO-1996-2184. DOE Carlsbad Area Office, Carlsbad, NM.

4. Cranwell, R.M., Guzowski, R.V., Campbell, J.E., and Ortiz, N.R. 1990. Risk Methodology for Geologic Disposal of Radioactive Waste: Scenario Selection Procedure. NUREG/CR-1667, SAND80-1429. Sandia National Laboratories, Albuquerque, NM.

5. WIPP Performance Assessment Division. 1991. Preliminary Comparison with 40 CFR Part 191, Subpart B for the Waste Isolation Pilot Plant, December 1991. SAND91-0893. Sandia National Laboratories, Albuquerque, NM. Vols. 1-4.

6. WIPP Performance Assessment Department. 1992. Preliminary Performance Assessment for the Waste Isolation Pilot Plant, December 1992. SAND92-0700. Sandia National Laboratories, Albuquerque, NM. Vols. 1-5.

7. Stenhouse, M.J., Chapman, N.A., and Sumerling, T.J. 1993. SITE-94 Scenario Development FEP Audit List Preparation: Methodology and Presentation. SKI Technical Report 93:27. Swedish Nuclear Power Inspectorate, Stockholm. 
8. Goodwin, B.W., Stephens, M.E., Davison, C.C., Johnson, L.H., and Zach, R. 1994. Scenario Analysis for the Postclosure Assessment of the Canadian Concept for Nuclear Fuel Waste Disposal. AECL-10969, COG-94-247. Whiteshell Laboratories, Pinawa, Manitoba.

9. Andersson, J., Ed. 1989. The Joint SKI/SKB Scenario Development Project. SKB Technical Report 89-35, Authors: J. Andersson, T. Carlsson, T. Eng, F. Kautsky, E. Söderman, and S. Wingefors. Swedish Nuclear Fuel and Waste Management Co., Stockholm, Sweden.

10. NAGRA (National Cooperative for the Storage of Radioactive Waste). 1985. Nuclear Waste Management in Switzerland: Feasibility Studies and Safety Analyses (Project Gewahr, 1985). NAGRA Project Report NGB 85-09 (English Summary). NAGRA, Wettingen.

11. Thorne, M.C. 1992. Dry Run 3 - A Trial Assessment of Underground Disposal of Radioactive Wastes Based on Probabilistic Risk Analysis - Volume 8: Uncertainty and Bias Audit. United Kingdom Department of Environment Report DOE/HMIP/RR/92.040. DOE, London.

12. Miller, W.M. and Chapman, N.A., Ed. 1992. Identification of Relevant Processes, System Concept Group Report, UKDOE/HMIP Report TR-ZI-11. DOE, London.

13. Hodgkinson, D.P. and Sumerling, T.J. 1989. A Review of Approaches to Scenario Analysis for Repository Safety Assessment. In Proceedings of the LAEA/CEC/NEA (OECD) Symposium on Safety Assessment of Radioactive Waste Repositories (Paris, 1989). OECD/NEA, Paris. 333-350.

14. OECD Nuclear Energy Agency. 1992. Systematic Approaches to Scenario Development. Organisation for Economic Co-Operation and Development, Paris.

15. IAEA (International Atomic Energy Agency). 1981. Safety Assessment for the Underground Disposal of Radioactive Wastes. LAEA Safety Series No. 56, Vienna. 
16. Galson, D.A., Hicks, T.W., Wilmot, R.D., and Swift, P.N. 1995. Systems Prioritization Method $\square$ Iteration 2 Baseline Position Paper: Scenario Development for Long-Term Performance Assessments of the WIPP. Sandia National Laboratories, Albuquerque, NM. WPO 28726.

17. Froehlich, G.K., Williamson, M., and Ogden, H.C. "Computational Environment and Logistics for the 1996 Performance Assessment for the Waste Isolation Pilot Plant." Reliability Engineering \& System Safety (present issue).

18. Helton, J.C., Bean, J.E., Economy, K., Garner, J.W., MacKinnon, R.J., Miller, J., Schreiber, J.D., and Vaughn, P. "Uncertainty and Sensitivity Analysis for TwoPhase Flow in the Vicinity of the Repository in the 1996 Performance Assessment for the Waste Isolation Pilot Plant: Undisturbed Conditions." Reliability Engineering \& System Safety (present issue).

19. Helton, J.C., Bean, J.E., Economy, K., Garner, J.W., MacKinnon, R.J., Miller, J., Schreiber, J.D., and Vaughn, P. "Uncertainty and Sensitivity Analysis for TwoPhase Flow in the Vicinity of the Repository in the 1996 Performance Assessment for the Waste Isolation Pilot Plant: Disturbed Conditions." Reliability Engineering \& System Safety (present issue).

20. EPA (Environmental Protection Agency), 1998. $\square 40$ CFR Part 194: Criteria for the Certification and Re-Certification of the Waste Isolation Pilot Plant $\square$ s Compliance with the 40 CFR Part 191 Disposal Regulations: Certification Decision; Final Rule. $\square$ Federal Register, Vol. 63, No. 95, pp. 27353 - 27406. Office of Radiation and Indoor Air, Washington, D.C. 
Table 1. FEP lists used in deriving a checklist for the WIPP

\begin{tabular}{|l|c|c|}
\hline \multicolumn{1}{|c|}{ Study } & Country & Number of FEPs \\
\hline $\begin{array}{l}\text { Atomic Energy of Canada Limited (AECL) study of disposal of } \\
\text { spent fuel in crystalline rock }\end{array}$ & Canada & 275 \\
\hline $\begin{array}{l}\text { SKI \& Swedish Nuclear Fuel and Waste Management Company } \\
\text { (SKB) study of disposal of spent fuel in crystalline rock }\end{array}$ & Sweden & 157 \\
\hline $\begin{array}{l}\text { National Cooperative for the Storage of Radioactive Waste } \\
\text { (NAGRA) Project Gewähr study }\end{array}$ & Switzerland & 44 \\
\hline $\begin{array}{l}\text { UK Department of the Environment Dry Run 3 study of deep } \\
\text { disposal of low- and intermediate-level waste (L/LW) }\end{array}$ & UK & 305 \\
\hline $\begin{array}{l}\text { UK Department of Environment assessment of L/LW disposal in } \\
\text { volcanic rock at Sellafield }\end{array}$ & UK & 79 \\
\hline $\begin{array}{l}\text { UK Nuclear Industry Radioactive Waste Executive (NIREX) study } \\
\text { of the deep disposal of L/LW }{ }^{13}\end{array}$ & UK & 131 \\
\hline $\begin{array}{l}\text { Sandia National Laboratories (SNL) study of deep disposal of } \\
\text { spent fuel }\end{array}$ & US & 29 \\
\hline $\begin{array}{l}\text { NEA Working Group on Systematic Approaches to Scenario } \\
\text { Development }\end{array}$ & International & 122 \\
\hline International Atomic Energy Agency (IAEA) Safety Series & & 56 \\
\hline
\end{tabular}


Table 2. Categorization scheme for the CCA FEP list. The endpoint of the scheme, the detailed FEPs, are not shown here. The categorization hierarchy is up to four levels deep for each FEP. The entire FEP list, containing approximately 240 FEPs, is documented in Reference 3; the FEPs accounted for in PA calculations are listed in Tables 3 and 4 of this paper.

\begin{tabular}{|c|c|c|c|}
\hline NATURAL & Geological & Stratigraphy & \\
\hline & & Tectonics & \\
\hline & & Structural FEPs & Deformation \\
\hline & & & Fracture development \\
\hline & & & Fault movement \\
\hline & & & Seismic activity \\
\hline & & Crustal processes & Igneous activity \\
\hline & & & Metamorphism \\
\hline & & Geochemical FEPs & Dissolution \\
\hline & & & Mineralization \\
\hline & Subsurface hydrological & Groundwater characteristics & \\
\hline & & Changes in groundwater flow & \\
\hline & Subsurface geochemical & Groundwater geochemistry & \\
\hline & & $\begin{array}{l}\text { Changes in groundwater } \\
\text { chemistry }\end{array}$ & \\
\hline & Geomorphological & Physiography & \\
\hline & & Meteorite impact & \\
\hline & & Denudation & Weathering \\
\hline & & & Erosion \\
\hline & & & Sedimentation \\
\hline & & Soil development & \\
\hline & Surface hydrological & Fluvial & \\
\hline & & Lacustrine & \\
\hline & & $\begin{array}{l}\text { Groundwater recharge and } \\
\text { discharge }\end{array}$ & \\
\hline & & Changes in surface hydrology & \\
\hline & Climatic & Climate & \\
\hline & & Climate change & Meteorological \\
\hline & & & Glaciation \\
\hline & Marine & Seas & \\
\hline & & Marine sedimentology & \\
\hline & & Sea level changes & \\
\hline & Ecological & Flora \& fauna & \\
\hline & & Changes in flora \& fauna & \\
\hline \multirow[t]{9}{*}{$\begin{array}{l}\text { WASTE AND } \\
\text { REPOSITORY- } \\
\text { INDUCED }\end{array}$} & $\begin{array}{l}\text { Waste and repository } \\
\text { characteristics }\end{array}$ & Repository characteristics & \\
\hline & & Waste characteristics & \\
\hline & & Container characteristics & \\
\hline & & Seal characteristics & \\
\hline & & Back fill characteristics & \\
\hline & & Postclosure monitoring & \\
\hline & Radiological & Radioactive decay & \\
\hline & & Heat from radioactive decay & \\
\hline & & Nuclear criticality & \\
\hline
\end{tabular}


Table 2. Categorization scheme for the CCA FEP list. The endpoint of the scheme, the detailed FEPs, are not shown here. The categorization hierarchy is up to four levels deep for each FEP. The entire FEP list, containing approximately 240 FEPs, is documented in Reference 3; the FEPs accounted for in PA calculations are listed in Tables 3 and 4 of this paper.

\begin{tabular}{|c|c|c|c|}
\hline & & $\begin{array}{l}\text { Radiological effects on } \\
\text { material properties }\end{array}$ & \\
\hline t & Geological and mechanical & $\begin{array}{l}\text { Excavation-induced } \\
\text { fracturing }\end{array}$ & \\
\hline & & Rock creep & \\
\hline & & Roof falls & \\
\hline & & Subsidence & \\
\hline & & $\begin{array}{l}\text { Effects of fluid pressure } \\
\text { changes }\end{array}$ & \\
\hline & & Effects of explosions & \\
\hline & & Thermal effects & \\
\hline & & $\begin{array}{l}\text { Mechanical effects on } \\
\text { material properties }\end{array}$ & \\
\hline & $\begin{array}{l}\text { Subsurface hydrological and } \\
\text { fluid dynamical }\end{array}$ & Repository-induced flow & \\
\hline & & Effects of gas generation & \\
\hline & & Thermal effects & \\
\hline & Geochemical/chemical & Gas generation & Microbial gas generation \\
\hline & & & Corrosion \\
\hline & & & Radiolytic gas generation \\
\hline & & Chemical speciation & \\
\hline & & Precipitation / dissolution & \\
\hline & & Sorption & $m$ \\
\hline & & Reduction-oxidation chemistry & \\
\hline & & Organic complexation & \\
\hline & & Exothermic reactions & \\
\hline & & $\begin{array}{l}\text { Chemical effects on material } \\
\text { properties }\end{array}$ & \\
\hline & Contaminant transport mode & Solute transport & \\
\hline & & Colloid transport & \\
\hline & & Particulate transport & \\
\hline & & Microbial transport & \\
\hline & & Gas transport & \\
\hline & $\begin{array}{l}\text { Contaminant transport } \\
\text { process }\end{array}$ & Advection & \\
\hline & & Diffusion & \\
\hline & & $\begin{array}{l}\text { Thermochemical transport } \\
\text { phenomena }\end{array}$ & \\
\hline & & $\begin{array}{l}\text { Electrochemical transport } \\
\text { phenomena }\end{array}$ & \\
\hline & & $\begin{array}{l}\text { Physicochemical transport } \\
\text { phenomena }\end{array}$ & \\
\hline & Ecological & Plant, animal and soil uptake & \\
\hline & & Human uptake & \\
\hline HUMAN INITIATED & Geological & Drilling & \\
\hline & & Excavation activities & \\
\hline & & Subsurface explosions & Resource recovery \\
\hline
\end{tabular}


Table 2. Categorization scheme for the CCA FEP list. The endpoint of the scheme, the detailed FEPs, are not shown here. The categorization hierarchy is up to four levels deep for each FEP. The entire FEP list, containing approximately 240 FEPs, is documented in Reference 3; the FEPs accounted for in PA calculations are listed in Tables 3 and 4 of this paper.

\begin{tabular}{|l|l|l|l|}
\hline & & & $\begin{array}{l}\text { Underground nuclear } \\
\text { device testing }\end{array}$ \\
\hline & $\begin{array}{l}\text { Subsurface hydrological and } \\
\text { geochemical }\end{array}$ & Borehole fluid flow & Drilling-induced flow \\
\hline & & & Fluid extraction \\
\hline & & & Fluid injection \\
\hline & & & $\begin{array}{l}\text { Flow through abandoned } \\
\text { boreholes }\end{array}$ \\
\hline & & Excavation-induced flow & \\
\hline & Geomorphological & Lxplosion-induced flow & \\
\hline & Surface hydrological & Water control and use & \\
\hline & Climatic & $\begin{array}{l}\text { Anthropogenic climate } \\
\text { change }\end{array}$ & \\
\hline & Marine & Marine activities & \\
\hline & Ecological & Agricultural activities & \\
\hline & & $\begin{array}{l}\text { Social and technological } \\
\text { developments }\end{array}$ & \\
\hline
\end{tabular}


Table 3. Undisturbed performance FEPs and their treatment in performance assessment calculations

\begin{tabular}{|c|c|c|}
\hline FEP Categorization & $\begin{array}{c}\text { FEP } \\
\text { Incorpor- } \\
\text { ation }^{2}\end{array}$ & FEP Treatment ${ }^{b}$ \\
\hline \multicolumn{3}{|l|}{ NATURAL FEPS } \\
\hline \multicolumn{3}{|l|}{ Geological FEPs } \\
\hline \multicolumn{3}{|l|}{ Stratigraphy } \\
\hline Stratigraphy & $\mathrm{P}$ & Accounted for in the BRAGFLO model geometry \\
\hline \multicolumn{3}{|l|}{ Structural FEPs } \\
\hline \multicolumn{3}{|l|}{ Seismic activity } \\
\hline Seismic activity & $\mathrm{P}$ & $\begin{array}{l}\text { Accounted for in the DRZ permeability used by } \\
\text { BRAGFLO }\end{array}$ \\
\hline \multicolumn{3}{|l|}{ Geochemical FEPs } \\
\hline \multicolumn{3}{|l|}{ Dissolution } \\
\hline Shallow dissolution & $\mathrm{P}$ & Accounted for in the Culebra transmissivity fields \\
\hline \multicolumn{3}{|l|}{ Subsurface hydrological FEPs } \\
\hline \multicolumn{3}{|l|}{ Groundwater characteristics } \\
\hline Saturated groundwater flow & $\mathrm{C}$ & $\begin{array}{l}\text { Accounted for in BRAGFLO treatment of two- } \\
\text { phase flow, and in SECOFL2D representation of } \\
\text { flow in the Culebra }\end{array}$ \\
\hline $\begin{array}{l}\text { Unsaturated ground-water } \\
\text { flow }\end{array}$ & $\mathrm{C}$ & $\begin{array}{l}\text { Accounted for in BRAGFLO treatment of two- } \\
\text { phase flow }\end{array}$ \\
\hline Fracture flow & $\mathrm{C}$ & $\begin{array}{l}\text { Accounted for in SECOTP2D treatment of flow in } \\
\text { the Culebra }\end{array}$ \\
\hline $\begin{array}{ll}\begin{array}{l}\text { Effects of preferential } \\
\text { pathways }\end{array} \\
\end{array}$ & $\mathrm{P}$ & Accounted for in the Culebra transmissivity fields \\
\hline \multicolumn{3}{|l|}{ Subsurface geochemical FEPs } \\
\hline \multicolumn{3}{|l|}{ Groundwater geochemistry } \\
\hline Groundwater geochemistry & $P$ & $\begin{array}{l}\text { Accounted for in the actinide source term model, } \\
\text { and in the actinide transport and retardation model } \\
\text { used by SECOTP2D }\end{array}$ \\
\hline \multicolumn{3}{|l|}{ Geomorphological FEPs } \\
\hline \multicolumn{3}{|l|}{ Physiography } \\
\hline Physiography & $\overline{\mathrm{P}}$ & Accounted for in BRAGFLO model geometry \\
\hline \multicolumn{3}{|l|}{ Surface hydrological FEPs } \\
\hline \multicolumn{3}{|l|}{ Groundwater recharge and discharge } \\
\hline Groundwater discharge & $P$ & $\begin{array}{l}\text { Accounted for in specification of boundary } \\
\text { conditions to SECOFL2D }\end{array}$ \\
\hline Groundwater recharge & $P$ & $\begin{array}{l}\text { Accounted for in specification of boundary } \\
\text { conditions to SECOFL2D }\end{array}$ \\
\hline Infiltration & $P$ & $\begin{array}{l}\text { Accounted for in specification of boundary } \\
\text { conditions to SECOFL2D }\end{array}$ \\
\hline \multicolumn{3}{|l|}{ Changes in surface hydrology } \\
\hline $\begin{array}{l}\text { Changes in ground-water } \\
\text { recharge and discharge }\end{array}$ & $\mathrm{P}$ & Accounted for by the climate change model \\
\hline \multicolumn{3}{|l|}{ Climatic FEPs } \\
\hline \multicolumn{3}{|l|}{ Climate } \\
\hline $\begin{array}{l}\text { Precipitation (for example, } \\
\text { rainfall) }\end{array}$ & $P$ & Accounted for by the climate change model \\
\hline Temperature & $\mathrm{P}$ & Accounted for by the climate change model \\
\hline
\end{tabular}


Table 3. Undisturbed performance FEPs and their treatment in performance assessment calculations

\begin{tabular}{|c|c|c|}
\hline FEP Categorization & $\begin{array}{c}\text { FEP } \\
\text { Incorpor- } \\
\text { ation" }\end{array}$ & FEP Treatment ${ }^{b}$ \\
\hline \multicolumn{3}{|l|}{ Climate change } \\
\hline \multicolumn{3}{|l|}{ Meteorological } \\
\hline Climate change & $\mathbf{P}$ & Accounted for by the climate change model \\
\hline $\begin{array}{l}\text { WASTE- AND REPOSITORY-INDUCED } \\
\text { FEPs }\end{array}$ & & 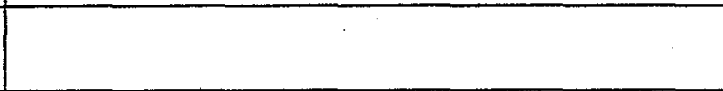 \\
\hline \multicolumn{3}{|l|}{ Waste and repository characteristics } \\
\hline \multicolumn{3}{|l|}{ Repository characteristics } \\
\hline Disposal geometry & $\mathbf{P}$ & Accounted for in BRAGFLO model geometry \\
\hline \multicolumn{3}{|l|}{ Waste characteristics } \\
\hline Waste inventory & $\mathbf{P}$ & Accounted for in the actinide source term model \\
\hline \multicolumn{3}{|l|}{ Container characteristics } \\
\hline $\begin{array}{l}\text { Container material } \\
\text { inventory }\end{array}$ & $\mathrm{P}$ & $\begin{array}{l}\text { Accounted for in cumulative distribution functions } \\
\text { (CDFs) for gas generation rates used by BRAGFLO }\end{array}$ \\
\hline \multicolumn{3}{|l|}{ Seal characteristics } \\
\hline Seal geometry & $\mathbf{P}$ & Accounted for in BRAGFLO model geometry \\
\hline Seal physical properties & $\bar{P}$ & $\begin{array}{l}\text { Accounted for in seal parameter values used by } \\
\text { BRAGFLO }\end{array}$ \\
\hline \multicolumn{3}{|l|}{ Backfill characteristics } \\
\hline $\begin{array}{l}\text { Backfill chemical } \\
\text { composition }\end{array}$ & $P$ & Accounted for in the actinide source term model \\
\hline \multicolumn{3}{|l|}{ Radiological FEPs } \\
\hline \multicolumn{3}{|l|}{ Radioactive decay } \\
\hline $\begin{array}{l}\begin{array}{l}\text { Radionuclide decay and } \\
\text { ingrowth }\end{array} \\
\end{array}$ & $\mathrm{C}$ & Accounted for in NUTS, PANEL and SECOTP2D \\
\hline \multicolumn{3}{|l|}{ Geological and mechanical FEPs } \\
\hline \multicolumn{3}{|l|}{ Excavation-induced fracturing } \\
\hline Disturbed rock zone & $\mathrm{P}$ & $\begin{array}{l}\text { Accounted for in BRAGFLO parameter values and } \\
\text { materials definition }\end{array}$ \\
\hline $\begin{array}{l}\text { Excavation-induced } \\
\text { changes in stress }\end{array}$ & $P$ & $\begin{array}{l}\text { Accounted for in the creep closure model in } \\
\text { BRAGFLO }\end{array}$ \\
\hline \multicolumn{3}{|l|}{ Rock creep } \\
\hline Salt creep & $P$ & $\begin{array}{l}\text { Accounted for in the creep closure model in } \\
\text { BRAGFLO }\end{array}$ \\
\hline Changes in the stress field & $P$ & $\begin{array}{l}\text { Accounted for in the creep closure model in } \\
\text { BRAGFLO }\end{array}$ \\
\hline \multicolumn{3}{|l|}{ Roof falls } \\
\hline Roof falls & $P$ & $\begin{array}{l}\text { Accounted for in the permeability of the DRZ used } \\
\text { by BRAGFLO }\end{array}$ \\
\hline \multicolumn{3}{|l|}{ Effects of fluid pressure changes } \\
\hline $\begin{array}{l}\text { Disruption due to gas } \\
\text { effects }\end{array}$ & $\mathrm{C}$ & $\begin{array}{l}\text { Accounted for in BRAGFLO fracture model for } \\
\text { Salado interbeds }\end{array}$ \\
\hline Pressurization & C & $\begin{array}{l}\text { Accounted for in BRAGFLO fracture model for } \\
\text { Salado interbeds }\end{array}$ \\
\hline \multicolumn{3}{|l|}{ Effects of explosions } \\
\hline Gas explosions & $\mathrm{P}$ & $\begin{array}{l}\text { Accounted for in the permeability of the DRZ used } \\
\text { by BRAGFLO }\end{array}$ \\
\hline
\end{tabular}


Table 3. Undisturbed performance FEPs and their treatment in performance assessment calculations

\begin{tabular}{|c|c|c|}
\hline FEP Categorization & $\begin{array}{c}\text { FEP } \\
\text { Incorpor- } \\
\text { ation" }\end{array}$ & FEP Treatment $^{\mathrm{b}}$ \\
\hline \multicolumn{3}{|l|}{$\begin{array}{l}\text { Mechanical effects on material } \\
\text { properties }\end{array}$} \\
\hline Consolidation of waste & $P$ & $\begin{array}{l}\text { Accounted for in the creep closure model in } \\
\text { BRAGFLO }\end{array}$ \\
\hline Consolidation of seals & $P$ & $\begin{array}{l}\text { Accounted for in seal parameters used by } \\
\text { BRAGFLO }\end{array}$ \\
\hline $\begin{array}{l}\text { Mechanical degradation of } \\
\text { seals }\end{array}$ & $\bar{P}$ & $\begin{array}{l}\text { Accounted for in seal parameters used by } \\
\text { BRAGFLO }\end{array}$ \\
\hline Underground boreholes & $P$ & $\begin{array}{l}\text { Accounted for in the permeability of the DRZ used } \\
\text { in BRAGFLO }\end{array}$ \\
\hline \multicolumn{3}{|l|}{$\begin{array}{l}\text { Subsurface hydrological and fluid dynamical } \\
\text { FEPs }\end{array}$} \\
\hline \multicolumn{3}{|l|}{ Repository-induced flow } \\
\hline Brine inflow & $\mathrm{C}$ & $\begin{array}{l}\text { Accounted for in BRAGFLO treatment of two- } \\
\text { phase flow }\end{array}$ \\
\hline Wicking & $\mathrm{P}$ & Accounted for in BRAGFLO gas generation model \\
\hline \multicolumn{3}{|l|}{ Effects of gas generation } \\
\hline $\begin{array}{l}\text { Fluid flow due to gas } \\
\text { production }\end{array}$ & $\mathrm{C}$ & $\begin{array}{l}\text { Accounted for in BRAGFLO treatment of two- } \\
\text { phase flow }\end{array}$ \\
\hline \multicolumn{3}{|l|}{ Geochemical and chemical FEPs } \\
\hline \multicolumn{3}{|l|}{ Gas generation } \\
\hline \multicolumn{3}{|l|}{ Microbial gas generation } \\
\hline $\begin{array}{l}\text { Degradation of organic } \\
\text { material }\end{array}$ & $\mathrm{C}$ & Accounted for in BRAGFLO gas generation model \\
\hline $\begin{array}{l}\text { Effects of temperature on } \\
\text { microbial gas generation }\end{array}$ & $\mathrm{P}$ & $\begin{array}{l}\text { Accounted for in CDFs for gas generation rates } \\
\text { used by BRAGFLO }\end{array}$ \\
\hline $\begin{array}{l}\text { Effects of biofilms on } \\
\text { microbial gas generation }\end{array}$ & $\mathrm{P}$ & $\begin{array}{l}\text { Accounted for in CDFs for gas generation rates } \\
\text { used by BRAGFLO }\end{array}$ \\
\hline \multicolumn{3}{|l|}{ Corrosion } \\
\hline Gases from metal corrosion & $\mathrm{C}$ & Accounted for in BRAGFLO gas generation model \\
\hline $\begin{array}{l}\text { Chemical effects of } \\
\text { corrosion }\end{array}$ & $\mathrm{P}$ & $\begin{array}{l}\text { Accounted for in CDFs for gas generation rates } \\
\text { used by BRAGFLO }\end{array}$ \\
\hline \multicolumn{3}{|l|}{ Chemical speciation } \\
\hline Speciation & $P$ & $\begin{array}{l}\text { Accounted for in the actinide source term model, } \\
\text { and in actinide transport and retardation model in } \\
\text { SECOTP2D }\end{array}$ \\
\hline \multicolumn{3}{|l|}{ Precipitation and dissolution } \\
\hline Dissolution of waste & $\mathrm{P}$ & Accounted for in the actinide source term model \\
\hline \multicolumn{3}{|l|}{ Sorption } \\
\hline Actinide sorption & $\mathrm{C}$ & $\begin{array}{l}\text { Accounted for in actinide retardation model in } \\
\text { SECOTP2D }\end{array}$ \\
\hline Kinetics of sorption & $\mathrm{P}$ & $\begin{array}{l}\text { Accounted for in actinide retardation model in } \\
\text { SECOTP2D }\end{array}$ \\
\hline $\begin{array}{l}\text { Changes in sorptive } \\
\text { surfaces }\end{array}$ & $\mathrm{P}$ & $\begin{array}{l}\text { Accounted for in actinide retardation model in } \\
\text { SECOTP2D }\end{array}$ \\
\hline \multicolumn{3}{|l|}{ Reduction-oxidation chemistry } \\
\hline Effect of metal corrosion & $\mathrm{P}$ & Accounted for in the actinide source term model \\
\hline
\end{tabular}


Table 3. Undisturbed performance FEPs and their treatment in performance assessment calculations

\begin{tabular}{|c|c|c|}
\hline FEP Categorization & $\begin{array}{c}\text { FEP } \\
\text { Incorpor- } \\
\text { ation }\end{array}$ & FEP Treatment ${ }^{b}$ \\
\hline $\begin{array}{l}\text { Reduction-oxidation } \\
\text { kinetics }\end{array}$ & $\mathrm{P}$ & Accounted for in the actinide source term model \\
\hline \multicolumn{3}{|l|}{ Organic complexation } \\
\hline Humic and fulvic acids & $P$ & $\begin{array}{l}\text { Accounted for in estimates of the colloidal actinide } \\
\text { source term }\end{array}$ \\
\hline \multicolumn{3}{|l|}{$\begin{array}{l}\text { Chemical effects on material } \\
\text { properties }\end{array}$} \\
\hline $\begin{array}{l}\text { Chemical degradation of } \\
\text { seals }\end{array}$ & $P$ & Accounted for in seal parameters in BRAGFLO \\
\hline $\begin{array}{ll}\begin{array}{l}\text { Microbial growth on } \\
\text { concrete }\end{array} \\
\end{array}$ & $\mathbf{P}$ & Accounted for in seal parameters in BRAGFLO \\
\hline \multicolumn{3}{|l|}{ Contaminant transport mode FEPs } \\
\hline \multicolumn{3}{|l|}{ Solute transport } \\
\hline Solute transport & $\mathrm{C}$ & $\begin{array}{l}\text { Accounted for by NUTS in the Salado and } \\
\text { SECOTP2D in the Culebra }\end{array}$ \\
\hline \multicolumn{3}{|l|}{ Colloid transport } \\
\hline Colloid transport & $\mathrm{C}$ & $\begin{array}{l}\text { Advection and diffusion of humic colloids in the } \\
\text { Culebra is estimated with SECOTP2D. }\end{array}$ \\
\hline $\begin{array}{l}\text { Colloid formation and } \\
\text { stability }\end{array}$ & $P$ & $\begin{array}{l}\text { Accounted for in the colloidal actinide source term } \\
\text { model. }\end{array}$ \\
\hline Colloid filtration & C & $\begin{array}{l}\text { Accounted for in treatment of transport for } \\
\text { microbial and mineral fragment colloidal particles. }\end{array}$ \\
\hline Colloid sorption & $\mathrm{C}$ & $\begin{array}{l}\text { Accounted for in estimates of humic colloid } \\
\text { retardation used by SECOTP2D. }\end{array}$ \\
\hline \multicolumn{3}{|l|}{ Microbial transport } \\
\hline Microbial transport & $\mathrm{C}$ & Accounted for by treatment of microbes as colloids. \\
\hline \multicolumn{3}{|l|}{ Contaminant transport processes } \\
\hline \multicolumn{3}{|l|}{ Advection } \\
\hline Advection & $\bar{C}$ & $\begin{array}{l}\text { Accounted for by NUTS in the Salado and } \\
\text { SECOTP2D in the Culebra }\end{array}$ \\
\hline \multicolumn{3}{|l|}{ Diffusion } \\
\hline Diffusion & $\mathrm{C}$ & Accounted for by SECOTP2D in the Culebra \\
\hline Matrix diffusion & $\mathrm{C}$ & Accounted for by SECOTP2D in the Culebra \\
\hline \multicolumn{3}{|l|}{ HUMAN-INITIATED FEPs } \\
\hline \multicolumn{3}{|l|}{ Excavation activities } \\
\hline \multicolumn{3}{|l|}{ Excavation activities } \\
\hline Potash mining & $P$ & $\begin{array}{l}\text { Potash mining outside the controlled area is } \\
\text { accounted for by modifying the Culebra. } \\
\text { transmissivity fields used by SECOFL2D }\end{array}$ \\
\hline \multicolumn{3}{|l|}{$\begin{array}{l}\text { Subsurface hydrological and } \\
\text { geochemical FEPs }\end{array}$} \\
\hline \multicolumn{3}{|l|}{ Borehole fluid flow } \\
\hline \multicolumn{3}{|l|}{ Drilling-induced flow } \\
\hline $\begin{array}{l}\text { Drilling-induced } \\
\text { geochemical changes }\end{array}$ & $\overline{\mathrm{P}}$ & Accounted for in SECOPT2D in the Culebra \\
\hline \multicolumn{3}{|l|}{ Fluid injection } \\
\hline $\begin{array}{l}\text { Fluid injection-induced } \\
\text { geochemical changes }\end{array}$ & $\bar{P}$ & Accounted for in SECOTP2D in the Culebra \\
\hline
\end{tabular}


Table 3. Undisturbed performance FEPs and their treatment in performance assessment calculations

\begin{tabular}{|c|c|l|}
\hline FEP Categorization & $\begin{array}{c}\text { FEP } \\
\text { Incorpor- } \\
\text { ation }^{\mathbf{2}}\end{array}$ & \\
\hline $\begin{array}{c}\text { Flow through abandoned } \\
\text { boreholes }\end{array}$ & & FEP Treatment $^{\mathrm{b}}$ \\
\hline $\begin{array}{c}\text { Borehole-induced } \\
\text { geochemical changes }\end{array}$ & $\mathrm{P}$ & Accounted for in SECOTP2D in the Culebra \\
\hline Excavation-induced flow & & \\
\hline $\begin{array}{l}\text { Changes in groundwater } \\
\text { flow due to mining }\end{array}$ & $\mathrm{P}$ & $\begin{array}{l}\text { Potash mining outside the controlled area is } \\
\text { accounted for by modifying the Culebra } \\
\text { transmissivity fields used by SECOFL2D }\end{array}$ \\
\hline
\end{tabular}

Notes:

${ }^{\mathrm{a}} \mathrm{C}$ FEP treated through explicit representation in the equations implemented in the performance assessment code.

P FEP treated through the specification of parameters values.

${ }^{b}$ BRAGFLO, SECOFL2D, SECOTP2D, NUTS, and PANEL are codes used directly in performance assessment calculations. These codes and their inter-relationships are described in Reference 17. 
Table 4. Disturbed performance FEPs and their treatment in performance assessment calculations

\begin{tabular}{|c|c|c|c|}
\hline FEP Categorization & Scenario $^{2}$ & $\begin{array}{c}\text { FEP } \\
\text { Incorpor- } \\
\text { ation }^{\mathrm{b}} \\
\end{array}$ & FEP Treatment ${ }^{c}$ \\
\hline \multicolumn{4}{|l|}{$\begin{array}{l}\text { ALL UNDISTURBED PERFORMANCE } \\
\text { FEPs (see Table 3) }\end{array}$} \\
\hline \multicolumn{4}{|l|}{ NATURAL FEPs } \\
\hline \multicolumn{4}{|l|}{ Geological FEPs } \\
\hline \multicolumn{4}{|l|}{ Stratigraphy } \\
\hline Brine reservoirs & $\mathrm{E} 1$ & $\mathrm{C}$ & Accounted for in BRAGFLO \\
\hline \multicolumn{4}{|l|}{$\begin{array}{l}\text { WASTE- AND REPOSITORY-INDUCED } \\
\text { FEPs }\end{array}$} \\
\hline \multicolumn{4}{|l|}{ Waste and repository characteristics } \\
\hline \multicolumn{4}{|l|}{ Waste characteristics } \\
\hline $\begin{array}{l}\text { Heterogeneity of waste } \\
\text { forms }\end{array}$ & $E 1, E 2$ & $P$ & $\begin{array}{l}\text { Accounted for in the waste activity } \\
\text { probabilities used by CCDFGF }\end{array}$ \\
\hline \multicolumn{4}{|l|}{ Contaminant transport mode FEPs } \\
\hline \multicolumn{4}{|l|}{ Particulate transport } \\
\hline Suspensions of particles & $\mathrm{E} 1, \mathrm{E} 2$ & $\mathrm{C}$ & $\begin{array}{l}\text { Accounted for in CUTTINGS_S } \\
\text { treatment of releases through boreholes }\end{array}$ \\
\hline Cuttings & $\mathrm{E} 1, \mathrm{E} 2$ & $\mathrm{C}$ & $\begin{array}{l}\text { Accounted for in CUTTINGS S } \\
\text { treatment of releases through boreholes }\end{array}$ \\
\hline Cavings & $\mathrm{E} 1, \mathrm{E} 2$ & $\bar{C}$ & $\begin{array}{l}\text { Accounted for in CUTTINGS_S } \\
\text { treatment of releases through boreholes }\end{array}$ \\
\hline Spallings & $\mathrm{E} 1, \mathrm{E} 2$ & $\mathrm{C}$ & $\begin{array}{l}\text { Accounted for in CUTTINGS_S } \\
\text { treatment of releases through boreholes }\end{array}$ \\
\hline \multicolumn{4}{|l|}{ HUMAN-INITIATED FEPS } \\
\hline \multicolumn{4}{|l|}{ Geological FEPs } \\
\hline \multicolumn{4}{|l|}{ Drilling } \\
\hline Oil and gas exploration & $\mathrm{E} 1, \mathrm{E} 2$ & $\mathrm{P} \cdot$ & $\begin{array}{l}\text { Drilling of deep boreholes is accounted } \\
\text { for in estimates of drilling frequency } \\
\text { used by CCDFGF }\end{array}$ \\
\hline Potash exploration & $\mathrm{E} 1, \mathrm{E} 2$ & $\mathbf{P}$ & $\begin{array}{l}\text { Drilling of deep boreholes is accounted } \\
\text { for in estimates of drilling frequency } \\
\text { used by CCDFGF }\end{array}$ \\
\hline Oil and gas exploitation & $\mathrm{E} 1, \mathrm{E} 2$ & $\mathbf{P}$ & $\begin{array}{l}\text { Drilling of deep boreholes is accounted } \\
\text { for in estimates of drilling frequency } \\
\text { used by CCDFGF }\end{array}$ \\
\hline Other resources & $\mathrm{E} 1, \mathrm{E} 2$ & $\mathrm{P}$ & $\begin{array}{l}\text { Drilling of deep boreholes is accounted } \\
\text { for in estimates of drilling frequency } \\
\text { used by CCDFGF }\end{array}$ \\
\hline $\begin{array}{l}\text { Enhanced oil and gas } \\
\text { recovery }\end{array}$ & $\mathrm{E} 1, \mathrm{E} 2$ & $\bar{P}$ & $\begin{array}{l}\text { Drilling of deep boreholes is accounted } \\
\text { for in estimates of drilling frequency } \\
\text { used by CCDFGF }\end{array}$ \\
\hline \multicolumn{4}{|l|}{ Excavation activities } \\
\hline Potash mining & $\mathrm{M}$ & $P$ & $\begin{array}{l}\text { Potash mining inside the controlled area } \\
\text { is accounted for by modifying the } \\
\text { Culebra transmissivity fields used by } \\
\text { SECOFL2D }\end{array}$ \\
\hline $\begin{array}{l}\text { Subsurface hydrological and geochemical } \\
\text { FEPs }\end{array}$ & & & \\
\hline
\end{tabular}


Table 4. Disturbed performance FEPs and their treatment in performance assessment calculations

\begin{tabular}{|c|c|c|c|}
\hline FEP Categorization & Scenario ${ }^{a}$ & $\begin{array}{c}\text { FEP } \\
\text { Incorpor- } \\
\text { ation }^{b} \\
\end{array}$ & FEP Treatment ${ }^{c}$ \\
\hline \multicolumn{4}{|l|}{ Borehole fluid flow } \\
\hline \multicolumn{4}{|l|}{ Drilling-induced flow } \\
\hline Drilling fluid flow & $E 1, E 2$ & $\mathrm{C}$ & $\begin{array}{l}\text { Accounted for in spallings and direct } \\
\text { brine release models }\end{array}$ \\
\hline Drilling fluid loss & E2 & $P$ & $\begin{array}{l}\text { Accounted for in the BRAGFLO } \\
\text { treatment of brine flow }\end{array}$ \\
\hline Blowouts & $E 1, E 2$ & $\mathrm{C}$ & $\begin{array}{l}\text { Accounted for in spallings and direct } \\
\text { brine release models }\end{array}$ \\
\hline $\begin{array}{l}\text { Drilling-induced } \\
\text { geochemical changes }\end{array}$ & $\mathrm{E} 1, \mathrm{E} 2$ & $P$ & $\begin{array}{l}\text { Accounted for by SECOTP2D in the } \\
\text { Culebra }\end{array}$ \\
\hline \multicolumn{4}{|l|}{ Flow through abandoned boreholes } \\
\hline $\begin{array}{l}\text { Natural borehole fluid } \\
\text { flow }\end{array}$ & $\mathrm{E} 1, \mathrm{E} 2$ & $\bar{C}$ & $\begin{array}{l}\text { Accounted for in BRAGFLO treatment } \\
\text { of long-term releases through boreholes }\end{array}$ \\
\hline $\begin{array}{l}\text { Waste-induced borehole } \\
\text { flow }\end{array}$ & $\mathrm{El}, \mathrm{E} 2$ & $\mathrm{C}$ & $\begin{array}{l}\text { Accounted for in BRAGFLO treatment } \\
\text { of long-term releases through boreholes }\end{array}$ \\
\hline $\begin{array}{l}\text { Borehole-induced } \\
\text { geochemical changes }\end{array}$ & $E 1, E 2$ & $P$ & $\begin{array}{l}\text { Accounted for by SECOTP2D in the } \\
\text { Culebra }\end{array}$ \\
\hline \multicolumn{4}{|l|}{ Excavation-induced flow } \\
\hline $\begin{array}{l}\text { Changes in groundwater } \\
\text { flow due to mining }\end{array}$ & $\mathrm{M}$ & $P$ & $\begin{array}{l}\text { Potash mining inside the controlled area } \\
\text { is accounted for by modifying the } \\
\text { Culebra transmissivity fields used by } \\
\text { SECOFL2D }\end{array}$ \\
\hline \multicolumn{4}{|l|}{ Ecological FEPs } \\
\hline \multicolumn{4}{|l|}{$\begin{array}{l}\text { Social and technological } \\
\text { developments }\end{array}$} \\
\hline Loss of records & $\mathrm{M}, \mathrm{E} 1, \mathrm{E} 2$ & $P$ & $\begin{array}{l}\text { Accounted for in estimates of the prob- } \\
\text { ability of inadvertent human intrusion. }\end{array}$ \\
\hline
\end{tabular}

Notes:

${ }^{2} \mathrm{M}$ Mining within the controlled area.

E1 Deep drilling that intersects the waste disposal region and a brine reservoir in the Castile.

E2 Deep drilling that intersects a waste disposal panel.

${ }^{b} \mathrm{C}$ FEP treated through explicit representation in the equations implemented in the performance assessment codes.

$P \quad F E P$ treated through the specification of parameters values.

'BRAGFLO, CCDFGF, CUTTINGS_S, SECOFL2D, and SECOTP2D are codes used directly in performance assessment calculations. These codes and their inter-relationships are described in Reference 17.

${ }^{\mathrm{d}}$ Deep drilling means those drilling events in the Delaware Basin that reach or exceed a depth of 2,150 feet below the surface relative to where such drilling occurred. 


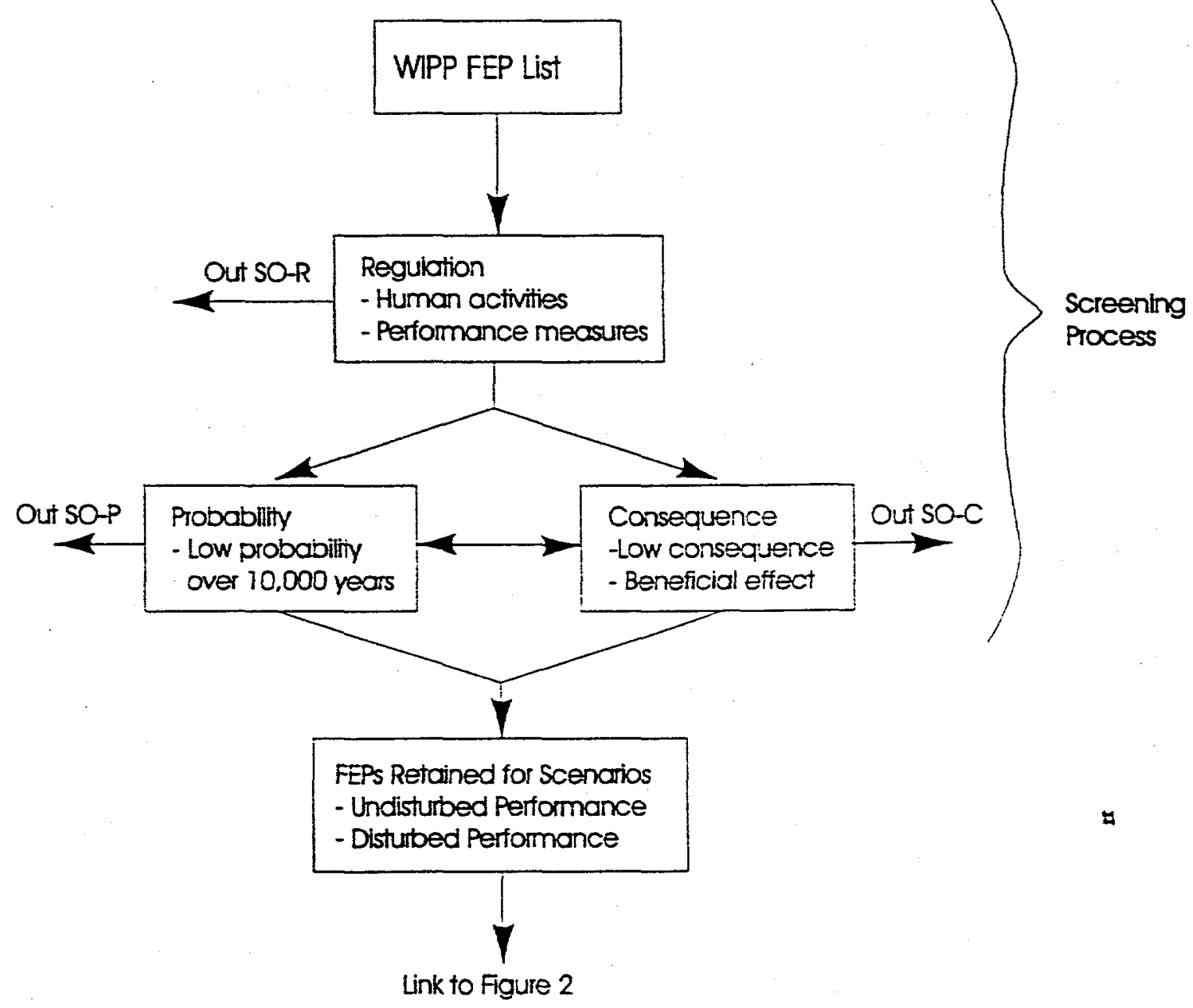

Figure 1. Screening process based on screening classifications. 


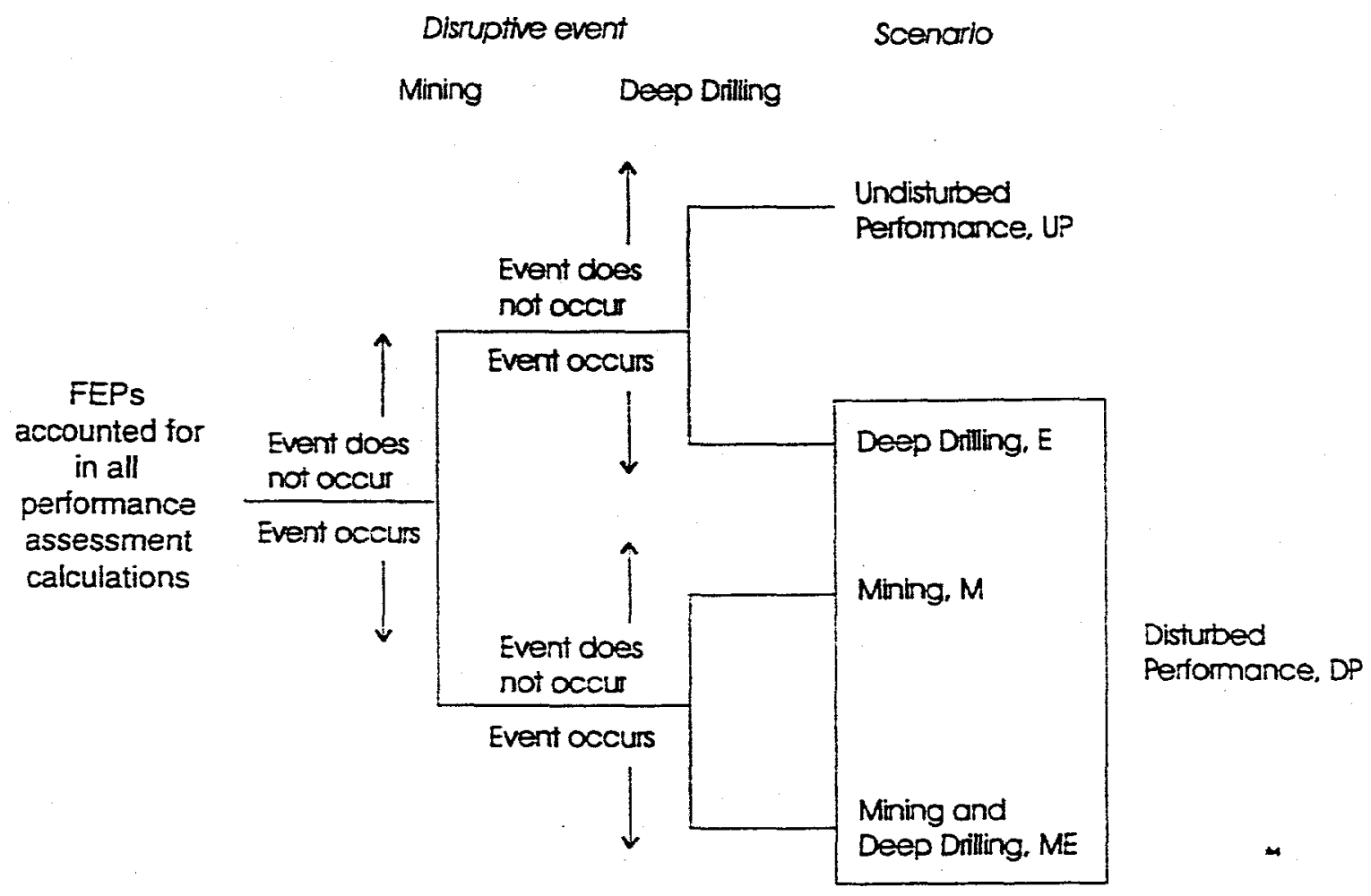

Figure 2. Logic diagram for scenario analysis. FEPs accounted for in all performance assessment calculations have a probability of occurrence of one. Disruptive events used to form disturbed performance scenarios have an uncertain probability of occurrence. 


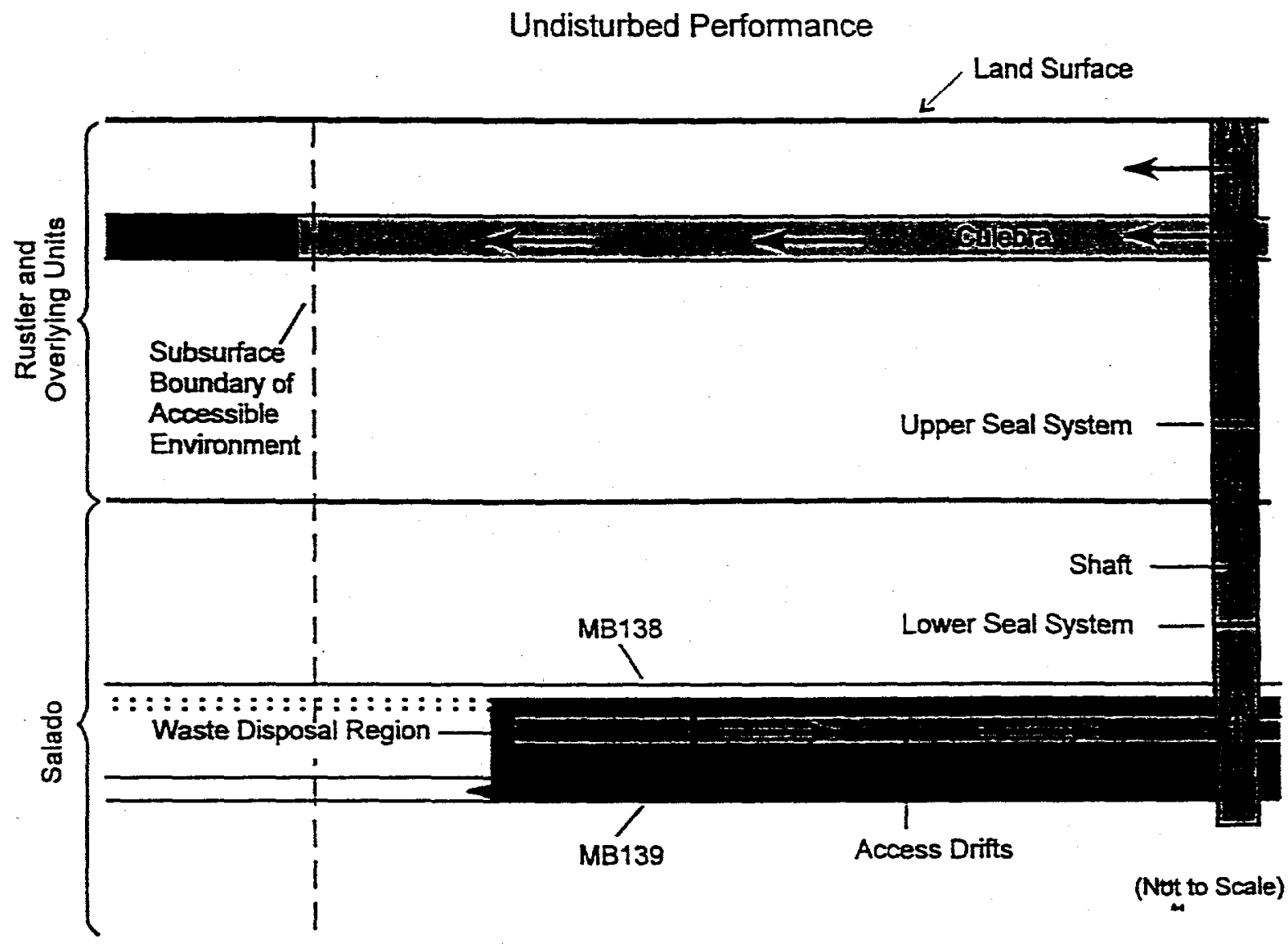

:::- Anhydrite layers $a$ and $b$ Culebra

Groundwater flow and radionuclide transport

Disturbed rock zone
Repository and shafts

Increase in Culebra hydraulic conductivity due to mining

Figure 3. Conceptual release pathways for the undisturbed performance scenario. 


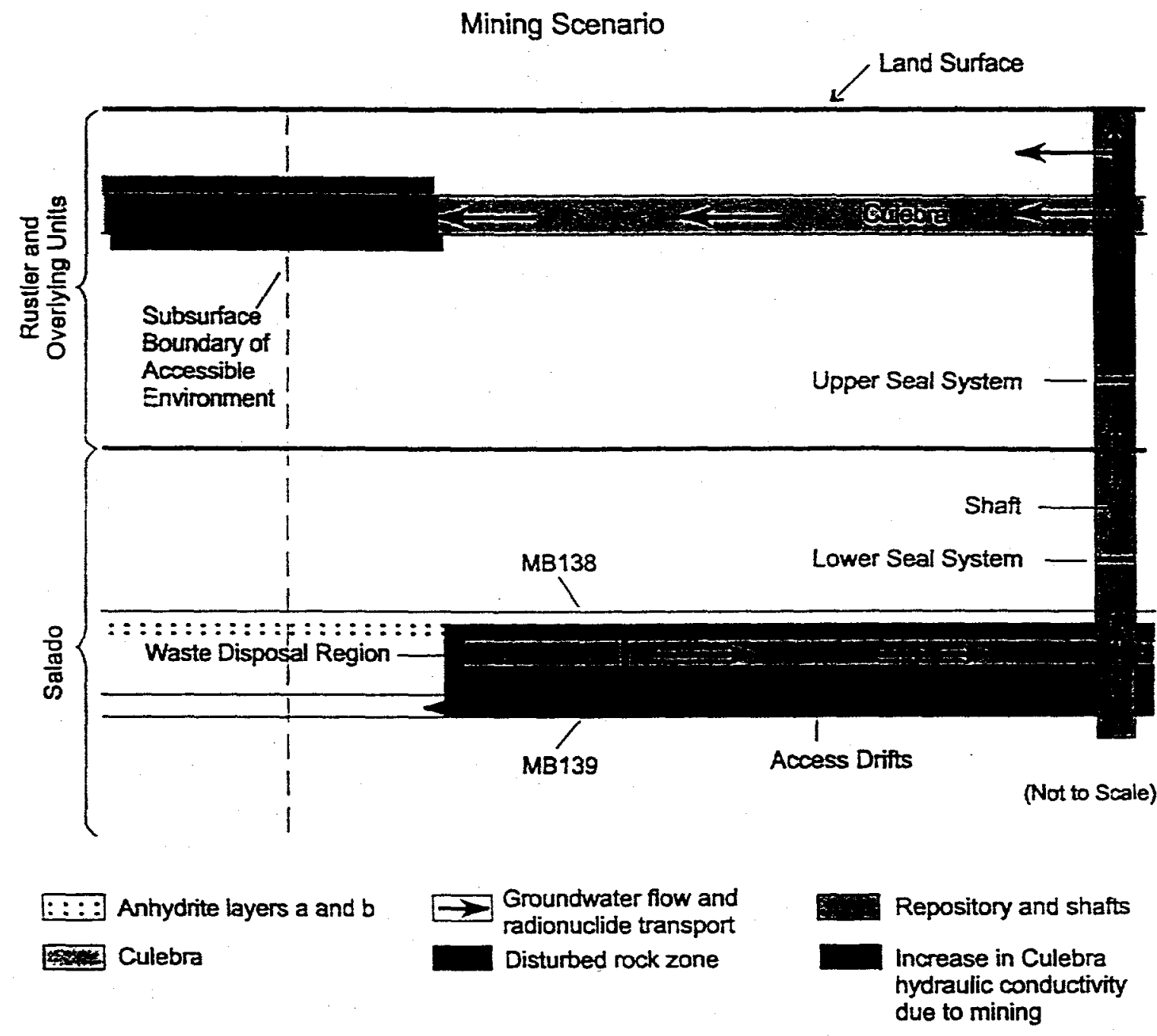

Figure 4. Conceptual release pathways for the disturbed performance mining scenario $\mathrm{M}$. 


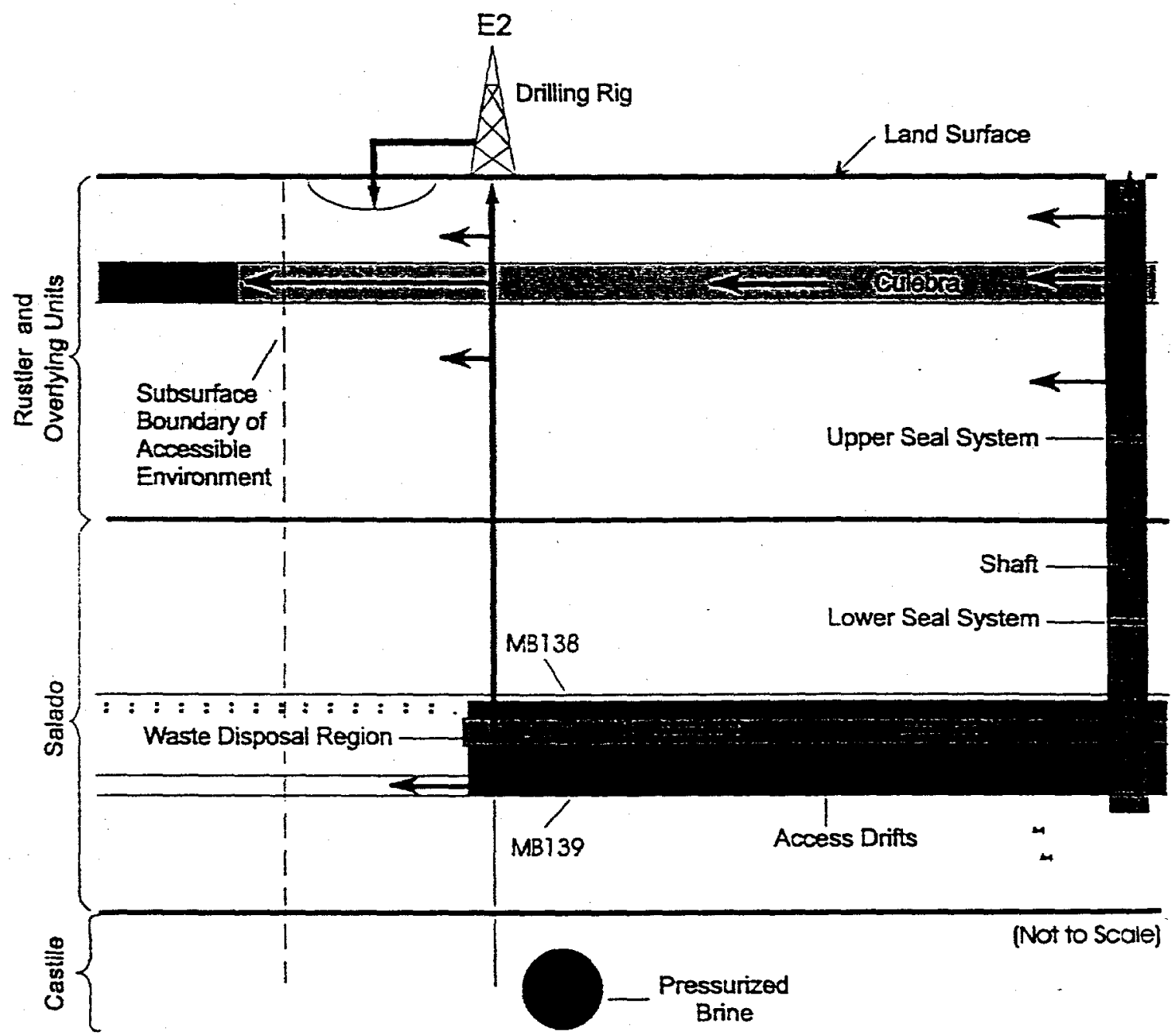

Note: Borehole penerrates waste and does not penetrate pressurized brine in the underlying Castile Formation. Arrows indicate bypothetical direction of groundwater flow and radionuclide transport.

::: Anhydrite layers $a$ and b

Fisa Culebra
Groundwater flow and radionuclide tansport

Disturbed rock zone

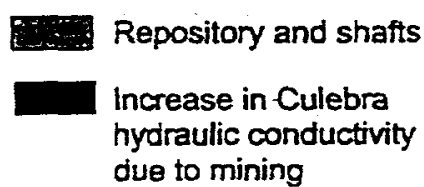

Figure 5. Conceptual release pathways for the disturbed performance deep drilling scenario E2. 


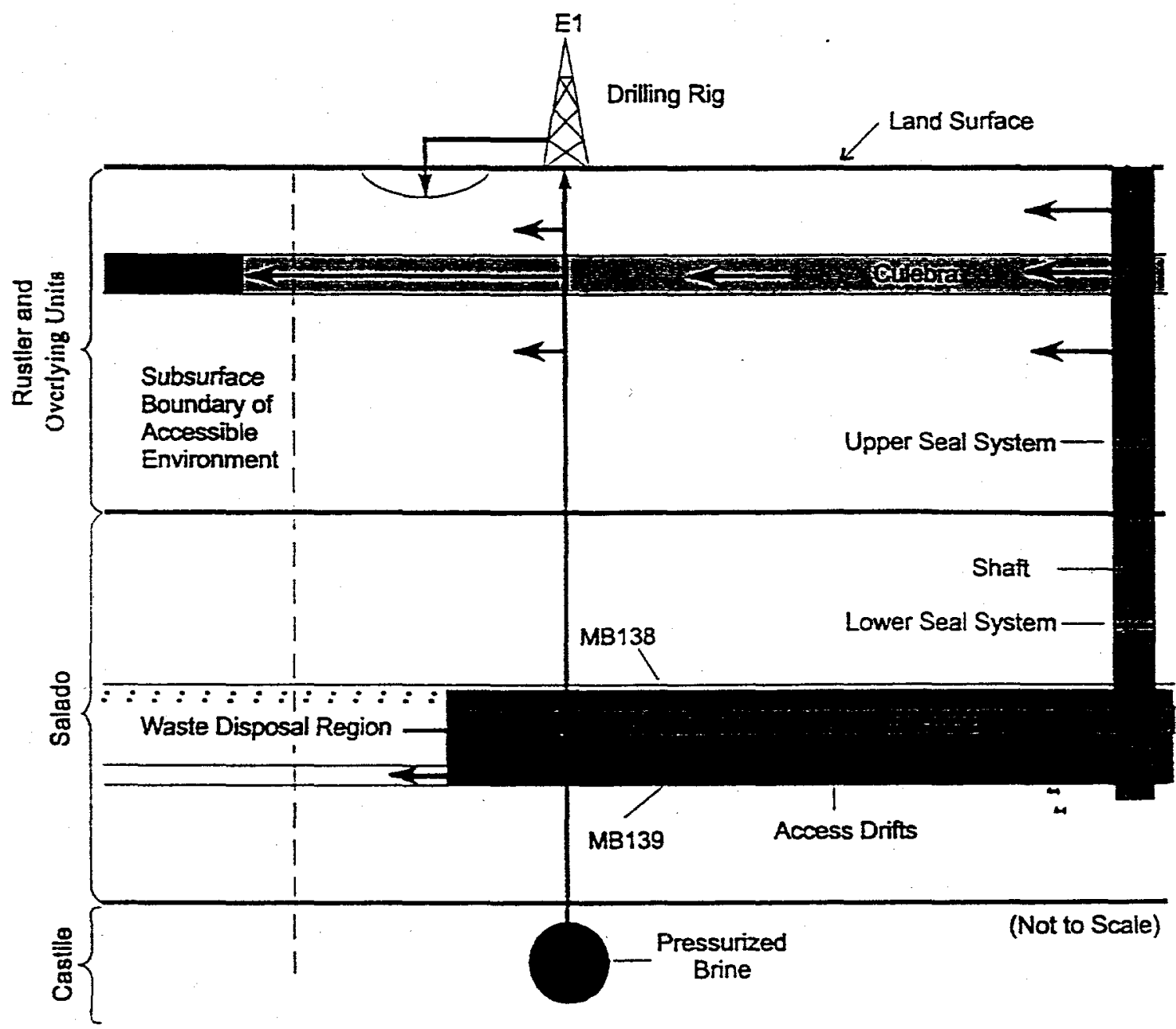

Note: Borehole penetrates waste and pressurized brine in the underlying Castile Formation. Arrows indicate bypothetical direction of groundwater flow and radionuclide transport.

.... Anhydrite layers $a$ and $b$

Culebra
Groundwater flow and radionuclide transport

Disturbed rock zone
Repository and shafts

Increase in Culebra hydraulic conductivity due to mining

Figure 6. Conceptual release pathways for the disturbed performance deep drilling scenario E1. 


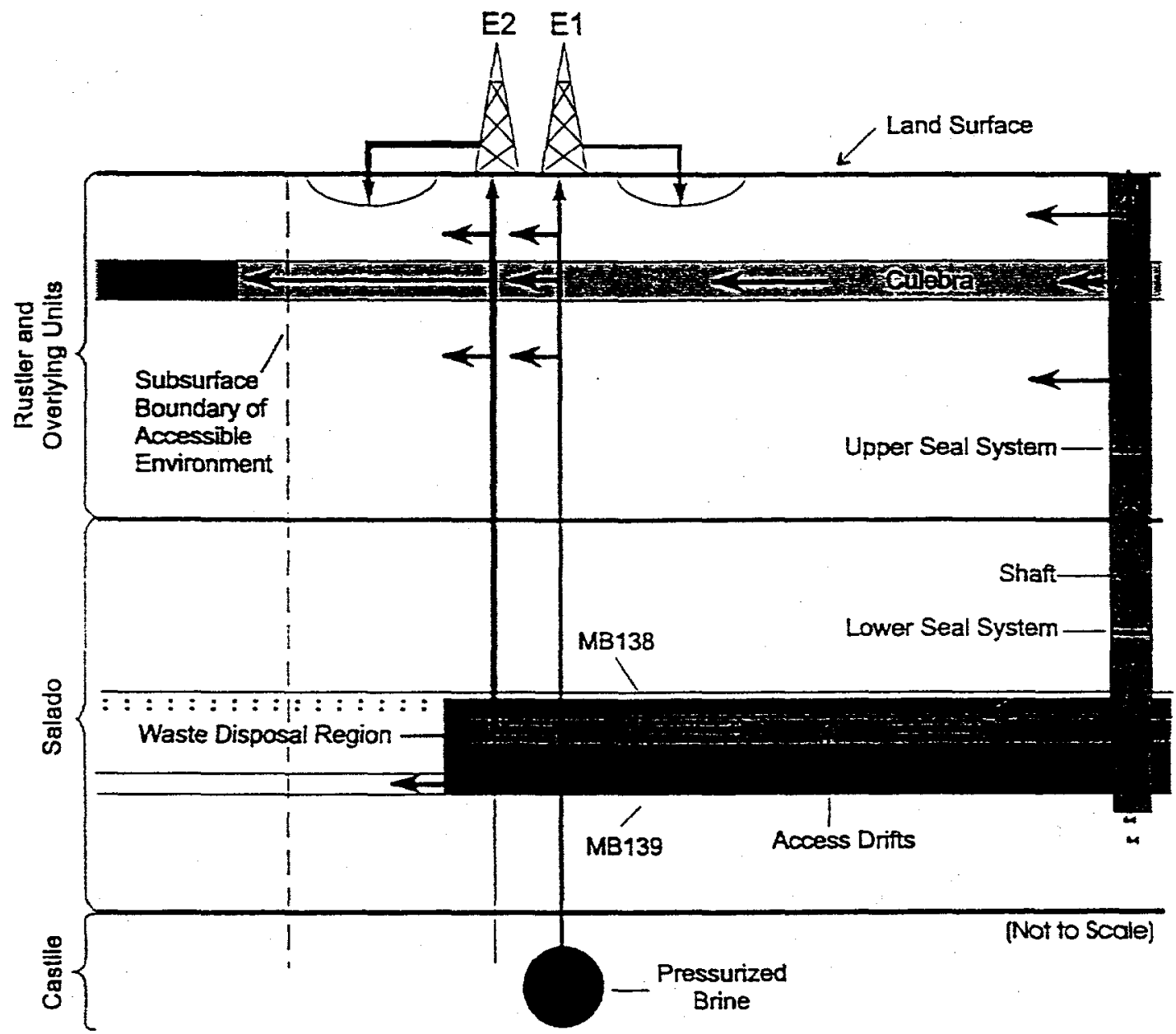

Note: Example shown includes only two boreholes, both of which penetrate waste and one of which penetrates pressurized brine in the underlying Castile Formation. Pathways are similar for examples containing multiple boreholes. Arrows indicate bypothetical direction of groundwater flow and racionuclide transport

.... Anhydrite layers $a$ and b $\begin{aligned} & \text { Groundwater flow and } \\ & \text { radionuclide transport } \\ & \text { Disturbed rock zone }\end{aligned}$
Culebra

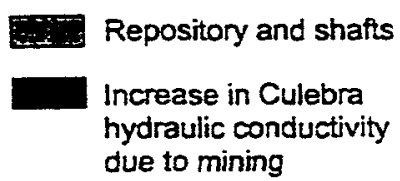

Figure 7. Conceptual release pathways for the disturbed performance deep drilling scenario E1E2. 